Solid Earth Discuss., https://doi.org/10.5194/se-2019-56

Manuscript under review for journal Solid Earth

Discussion started: 20 March 2019

(c) Author(s) 2019. CC BY 4.0 License.

\title{
Late Miocene thrusting in the North Alpine foreland: Driven by a deep-seated process and shaped by the local mechanical stratigraphy
}

\author{
Samuel Mock ${ }^{1}$, Christoph von Hagke ${ }^{2}$, Fritz Schlunegger ${ }^{1}$, István Dunkl ${ }^{3}$, Marco Herwegh ${ }^{1}$ \\ ${ }^{1}$ Institute of Geological Sciences, University of Bern, Baltzerstrasse 1+3, 3012 Bern, Switzerland \\ 5 '2Institute of Geology and Palaeontology, RWTH Aachen University Wüllnerstrasse 2, 52056 Aachen, Germany \\ ${ }^{3}$ Geoscience Center, Sedimentology and Environmental Geology, University of Göttingen Goldschmidtstrasse 3, 37077 \\ Göttingen, Germany
}

Correspondence to: Samuel Mock (samuel.mock@geo.unibe.ch)

Abstract. Besides classical emplacement and accretion related nappe tectonics, the Oligocene to middle Miocene postcollisional evolution of the central European Alps was also characterized by pronounced vertically directed tectonics. These are expressed by backthrusting along the Insubric Line and the subsequent uplift of the External Crystalline Massifs (ECMs). During late Miocene times, the Central Alps experienced lateral growth when deformation propagated into the external parts of both the pro- and retro-side of the orogen. For the North Alpine foreland, pro-wedge propagation of deformation has been kinematically and spatially linked to the uplift and exhumation of the ECMs. In this paper, we investigate the young

15 exhumation history of the North Alpine foreland. Based on low-temperature apatite (U-Th-Sm)/He thermochronometry, we constrain thrusting in the Subalpine Molasse between $12 \mathrm{Ma}$ and $5 \mathrm{Ma}$, thus occurring coeval to the main deformation phase in the adjacent Jura fold-and-thrust belt (FTB) and late stage exhumation of the ECMs. However, this pattern of tectonic activity is not restricted to areas which are bordered by the ECMs, but is consistent along the entire front of the Central Alps, regardless of its hinterland architecture. The local-scale pattern of strain partitioning and style of deformation is governed by lateral variations in the sedimentary foreland basin architecture. We suggest that the large-scale constant tectonic signal is the response to a shift in tectonic forces caused by a deep-seated geodynamic process. This resulted in a change from dominantly vertical to orogen-scale horizontal tectonics and an associated orogen-perpendicular growth of crustal thickening. We constrain the onset of this major tectonic change to ca. $15 \mathrm{Ma}$ in the Southern Alps and ca. $12 \mathrm{Ma}$ in the North Alpine foreland, where it results in (re-)activation of thrusts in the Subalpine Molasse and folding in the Jura FTB.

\section{Introduction}

Deep crustal processes and slab dynamics influence the evolution of mountain belts (e.g., Davies and von Blanckenburg, 1995; Molnar et al., 1993; Oncken et al., 2006). However, these deep-seated signals may be masked by tectonic forcing at upper crustal levels and by enhanced surface erosion related to stages of climate change (e.g., Champagnac et al., 2007; Chemenda et al., 2000; Whipple, 2009; Willett et al., 2006). In near surface crustal domains, it is thus challenging to isolate the exhumation signal related to slab dynamics. Foreland basins may resolve the influence of deep-seated processes on 
Solid Earth Discuss., https://doi.org/10.5194/se-2019-56

Manuscript under review for journal Solid Earth

Discussion started: 20 March 2019

(c) Author(s) 2019. CC BY 4.0 License.

mountain building, as they are able to record signals related to surface dynamics such as changes of sediment fluxes and eustacy (e.g. Pippèrr and Reichenbacher, 2017; Sinclair and Allen, 1992), but also at long timescales and large wavelengths (e.g. DeCelles and Giles, 1996; Garefalakis and Schlunegger, 2018; Leary et al., 2016). The North Alpine foreland is particularly suited to constrain the geodynamic evolution of a collisional orogen because the history of its Molasse Basin has been well established through numerous magneto- and tectonostratigraphic (e.g. Burkhard and Sommaruga, 1998; Ganss and Schmidt-Thomé, 1953; Homewood et al., 1986; Kempf et al., 1999; Pfiffner, 1986; Schlunegger et al., 1996; Sinclair et al., 1991), seismic (Hinsch, 2013; Mock and Herwegh, 2017; Ortner et al., 2015; Sommaruga et al., 2012), and low-temperature thermochronological studies (Cederbom et al., 2004, 2011, von Hagke et al., 2012, 2014; Mazurek et al., 2006).

Studies from the forelands of the European Alps have shown that the most external parts of the orogen were incorporated 10 into the orogenic wedge in Miocene times (Becker, 2000; Burkhard, 1990; von Hagke et al., 2012, 2014; Hinsch, 2013; Ortner et al., 2015; Pfiffner, 1986; Schmid et al., 1996; Schönborn, 1992). In the case of the North Alpine foreland, late Miocene deformation has been kinematically and spatially linked to the uplift and exhumation of the External Crystalline Massifs (ECMs; e.g. Burkhard, 1990; Burkhard and Sommaruga, 1998; von Hagke et al., 2014; Pfiffner, 1986). The latter represent crystalline blocks (e.g. Aar Massif) derived from the subducting European plate, i.e. the Helvetic realm (Schmid et

15 al., 2004). These concepts of foreland deformation are based on a classical scenario of continent-continent collision, where compressional wedge tectonics and shortening result in propagation of the orogenic wedge towards the foreland, including imbricate thrusting (Pfiffner, 1986; Rosenberg and Berger, 2009; Schmid et al., 1996). However, foreland propagation of deformation was not continuous as shown by structural, chronostratigraphic, and low-temperature thermochronological data, indicating that the Alpine thrust front advanced rather discontinuously during Miocene times (Burkhard and Sommaruga,

20 1998; von Hagke et al., 2014; Ortner et al., 2015). These studies though all indicate km-scale shortening in the North Alpine foreland during the late stage of orogenic evolution. Similarly, shortening since the Miocene has been reported for the foreland FTB of the Southern Alps (refs.). Schlunegger and Simpson (2002) suggested that Miocene orogenic widening of the Central Alps is the result of gravitational forces, as the mechanical state of the Alpine wedge became supercritical. Alternatively, erosion-induced extension in the orogen may cause shortening in the foreland FTBs on both sides of the orogen (Vernant et al., 2013). Other authors have related lateral growth of the orogen to changes in the rheology and in the deep structure of the Western and Central Alps (Rosenberg and Berger, 2009) and to rotation of the Dolomites indenter in the Eastern Alps (Rosenberg et al., 2015). In a subsequent analysis of the Central Alps, gently south-dipping thrusts in the Aar Massif, which were associated with compression, were related to post-12 Ma horizontal shortening (Herwegh et al., 2017) post-dating a strong event of buoyancy-driven subvertical uplift (22-14 Ma). Despite differing in the assignment of the

30 principal driving mechanisms, these articles concur on the observation that there was an overall change in kinematics, showing a shift in direction of tectonic movement from a dominantly vertical to a dominantly horizontal component, and it is this change of thrust tectonics that results in shortening in the foreland thrust systems, i.e. the Jura FTB and the Subalpine Molasse. What is so far only incompletely resolved is (i) the strain partitioning between the Jura FTB and the Subalpine 
Solid Earth Discuss., https://doi.org/10.5194/se-2019-56

Manuscript under review for journal Solid Earth

Discussion started: 20 March 2019

(c) Author(s) 2019. CC BY 4.0 License.

Molasse along strike and (ii) whether the amount of shortening within the Subalpine Molasse is consistent along strike, particularly with respect to the highly non-cylindrical architecture of the Alpine hinterland. However, this information is vital for understanding how deformation in the ECMs is linked to foreland FTB tectonics, and for ultimately making inferences on the drivers of orogen-perpendicular growth.

5 The proximal foreland basin deposits offer ideal archives where the most recent shortening history can be constrained. This is because the chronologic, tectonic, and stratigraphic framework of these sediments have been quantified at a high resolution, which resulted in a detailed picture of the history of sedimentation and the resulting mechanical stratigraphy, the tectonic style, as well as the amount of shortening (e.g. Burkhard and Sommaruga, 1998; von Hagke et al., 2012, 2014; Kempf et al., 1999; Ortner et al., 2015; Pfiffner, 1986; Schlunegger et al., 1997; and many others). This resulted in the

10 general notion that the basin experienced a phase of out-of-sequence thrusting postdating ca. 12-10 Ma. This thrusting in the Subalpine Molasse and the Jura FTB possibly coincided with or was followed by large-scale exhumation of the entire basin (Baran et al., 2014; Cederbom et al., 2004, 2011; Mazurek et al., 2006).

Geological mapping (e.g. Haldemann et al., 1980; Schlunegger et al., 2016; Weidmann et al., 1993; Zaugg et al., 2011) as well as stratigraphic work (Kempf et al., 1999; Schlunegger et al., 1993, 1997; Schlunegger and Kissling, 2015) has also

15 shown that the proximal basin border is characterized by large orogen-parallel lithologic variations where km-thick conglomerate suites with high mechanical strengths alternate with mudstones and sandstones with low at-yield conditions over short lateral distances of a few kilometers only. As a consequence, the patterns of thrust faults and folds within the Subalpine Molasse change where the km-thick conglomerate packages lead to km-spaced thrust faults with a relatively large displacement on them, while the structural style in regions made up of sandstone-mudstone alternations is characterized by

20 closely-spaced thrust faults and folds with possibly lower displacements. We expect that these differences in mechanical stratigraphy leave a distinct imprint on where strain is accommodated during orogenic shortening.

In this study, we present and discuss low-temperature thermochronological and tectono-sedimentological data along the entire thrusted Subalpine Molasse between $6.8^{\circ} \mathrm{E}$ (Lake Geneva) and $12.8^{\circ} \mathrm{E}$ (near Salzburg). We constrain the late stage of shortening based on new apatite (U-Th-Sm)/He ages from the Subalpine Molasse of Switzerland, which we combine with 25 previously published data (von Hagke et al., 2012, 2014) in order to constrain better the timing and spatial extent of the large-scale change from dominantly vertical to dominantly horizontal tectonics. We first discuss how the site-specific differences in the litho-tectonic architecture condition the pattern of strain partitioning within the proximal basin border. In a second step, we relate the data to the late stage large-scale horizontal shortening in the Alpine orogen and discuss them in the context of a possible geodynamic scenario. 
Solid Earth Discuss., https://doi.org/10.5194/se-2019-56

Manuscript under review for journal Solid Earth

Discussion started: 20 March 2019

(c) Author(s) 2019. CC BY 4.0 License.

\section{Geological background}

\subsection{Evolution of the Central Alps and their foreland}

The Central Alps are situated almost entirely on top of the subducted European lithospheric slab (Fig. 1; Schmid et al., 1996, 2017), which steeply dips into the asthenospheric mantle as imaged by teleseismic tomography (Lippitsch et al., 2003). The

5 bivergent orogen is the result of Late Cretaceous to Eocene ocean-continent subduction of the European plate under the Adriatic plate and subsequent post-35 Ma continent-continent collision (e.g. Schmid et al., 1996). The subduction system became clogged when the thick and buoyant European crust started to enter the subduction zone, which resulted in oceanic slab breakoff ca. 32 Myr ago (Davies and von Blanckenburg, 1995). Slab unloading and basal accretion of crustal segments to the Adriatic upper plate resulted in a period of fast uplift, which was mainly accommodated through backthrusting along

10 the Insubric Line (Hurford, 1986; Schmid et al., 1996). The signal of slab breakoff is also manifested in the rapid build-up of topography and in the subsequent increase of sediment discharge into the Alpine foreland (Schlunegger and Castelltort, 2016; Sinclair, 1997). During the Oligocene, Europe-derived sedimentary units were sheared off from their substratum and emplaced to the north over several tens of kilometers forming the present-day Helvetic cover nappes (Pfiffner, 2011, and references therein). Ongoing orogeny resulted in delamination of lower European crustal segments (Fry et al., 2010),

15 eventually inducing buoyancy-driven subvertical uplift (vertical tectonics) of the thickened crust (Kissling and Schlunegger, 2018) along steeply dipping shear zones and exhumation of the ECMs ca. 20 Myr ago (Fig. 1b; Herwegh et al., 2017).

The late stage in the evolution of the Alpine orogen is dominated by orogen-perpendicular growth due to the propagation of deformation to its external parts, i.e., to the Molasse Basin and the Jura fold-and-thrust belt (FTB) in the north, and to the Southern Alps in the south (Fig. 1; Burkhard, 1990; Pfiffner, 1986; Schmid et al., 1996; Schönborn, 1992), thereby marking

20 a change from dominantly vertical to horizontal tectonics (Schlunegger and Simpson, 2002). In the Southern Alps a foldand-thrust belt evolved during late Oligocene times (Schönborn, 1992), but the largest amounts of shortening occurred between ca. 15 Ma and 7 Ma (Schmid et al., 1996; Schönborn, 1992).

The Molasse Basin of the North Alpine foreland, which contains erosional products of the evolving Alps since $32 \mathrm{Ma}$ (Sinclair et al., 1991), is tectonically subdivided into the gently folded Plateau Molasse and the Subalpine Molasse. The latter consists of south-dipping imbricated thrust sheets and in large parts north-dipping backthrusts forming a triangle zone at the transition to the Plateau Molasse (Fig. 1b; Berge and Veal, 2005; Fuchs, 1976; Müller et al., 1988; Ortner et al., 2015; Schuller et al., 2015; Sommaruga et al., 2012). The Subalpine Molasse started to become incorporated into the orogenic wedge shortly after deposition in Oligocene times (Hinsch, 2013; Kempf et al., 1999; Pfiffner, 1986). However, it is noteworthy that after ca. $20 \mathrm{Ma}$, contemporaneously with the development of the frontal triangle zone, the northern Alpine

30 thrust front remained stationary in the area of the Subalpine Molasse (Burkhard and Sommaruga, 1998; von Hagke et al., 2014; Ortner et al., 2015). It was not until ca. 12 Ma when parts of the deformation in the western Molasse Basin propagated along a basal décollement zone within the Triassic evaporites into the thin-skinned Jura FTB (Becker, 2000; Burkhard and 
Solid Earth Discuss., https://doi.org/10.5194/se-2019-56

Manuscript under review for journal Solid Earth

Discussion started: 20 March 2019

(c) Author(s) 2019. CC BY 4.0 License.

Sommaruga, 1998; Laubscher, 1961; Philippe et al., 1996), although minor deformation of Late Oligocene age had occurred in the area of the today's Jura FTB (Aubert, 1958; Liniger, 1967). Hence, during the late Miocene, the Molasse Basin experienced significant along-strike changes in tectonic style and locus of deformation. While sediment accumulation in the eastern Molasse Basin occurred still in a foredeep setting, the western portion of the foredeep evolved at this stage into a

5 wedge-top basin (Willett and Schlunegger, 2010), as it was detached above the basal décollement. Both, the evaporite basal décollement and the thrusts of the Subalpine Molasse are considered to root below and in the ECMs. Accordingly, they were kinematically linked to the late Miocene exhumation of the ECMs (Fig. 1b; e.g. Burkhard, 1990), which was driven at that time by north-directed thrusting (Herwegh et al., 2017), thereby causing a phase of accelerated exhumation at ca. $10 \mathrm{Ma}$ (Glotzbach et al., 2010; Valla et al., 2012; Vernon et al., 2009; Weisenberger et al., 2012). Recently, new studies have 10 documented that the Subalpine Molasse was subject to break-back thrusting between ca. 13 Ma and 4 Ma (von Hagke et al., 2012, 2014; Ortner et al., 2015; Schuller et al., 2015), which was thus coeval to folding and thrusting in the Jura FTB.

After $10 \mathrm{Ma}$, but possibly as late as $5 \mathrm{Ma}$, the Molasse Basin was uplifted, resulting in large-scale erosion (Baran et al., 2014; Cederbom et al., 2004, 2011; von Hagke et al., 2012; Mazurek et al., 2006; Schlunegger and Mosar, 2011). Since 5 Ma, compressional thin-skinned tectonics in the wedge-top part of the basin and the Jura FTB are superseded by thick-

15 skinned tectonics (Giamboni et al., 2004; Guellec et al., 1990; Madritsch et al., 2008; Mock and Herwegh, 2017; Philippe et al., 1996; Ustaszewski and Schmid, 2007), while the internal Alps are currently under orogen-perpendicular extension possibly due to isostatic readjustments of the overthickened crust (Marschall et al., 2013; Sue et al., 2007).

\subsection{Molasse Basin stratigraphy}

The clastic infill of the Oligocene to Miocene peripheral Molasse Basin, situated on the northern side of the Alps, consists of

20 the eroded sediments of the evolving Alps. Accommodation space was formed through subsidence, classically related to flexural bending of the European plate in response to topographic loading of the advancing Alpine thrust wedge during Paleogene and Neogene times (Allen et al., 1991; Burkhard and Sommaruga, 1998; Karner and Watts, 1983; Pfiffner, 1986). This view has recently been challenged by Schlunegger and Kissling (2015), who favor a mechanism where vertical-directed slab loads exerted by the subducted European lithospheric mantle resulted in the bending of the foreland plate and the formation of accommodation space.

The Molasse sediments form two regressive and coarsening upward megasequences (Homewood et al., 1986; Kuhlemann and Kempf, 2002; Schlunegger et al., 2007). The first megasequence describes the transition from Rupelian sedimentation in underfilled conditions to Chattian-Aquitanian sedimentation when the basin was overfilled. The Burdigalian and postBurdigalian stratigraphic record then chronicles the second megasequence during filled to overfilled conditions (Sinclair and

30 Allen, 1992). Large alluvial megafans developed at the mountain front during the overfilled stage of the basin (Kuhlemann and Kempf, 2002). In their cores, close to the apex, large conglomerate bodies were deposited, while at the margins, the sedimentation was mainly sand- and mudstone dominated. At the proximal basin border, numerous locally-derived bajada 
Solid Earth Discuss., https://doi.org/10.5194/se-2019-56

Manuscript under review for journal Solid Earth

Discussion started: 20 March 2019

(c) Author(s) 2019. CC BY 4.0 License.

fans discharged sediments into the foreland and thus further contributed to the high along-strike stratigraphic variability at the proximal basin border (Kempf et al., 1999; Schlunegger et al., 1997; Spiegel et al., 2001).

\section{Methods}

\subsection{Sample sites and litho-tectonic architecture}

5 We collected 13 samples across the Subalpine Molasse east and west of Lake Thun for apatite (U-Th-Sm)/He (AHe) dating (Fig. 2). The northernmost samples represent coarse-grained Burdigalian sandstones of the Plateau Molasse. Further to the southwest, we sampled Chattian-Aquitanian and Rupelian sandstones within the Subalpine Molasse. Samples have been collected in the hanging- and footwalls of the individual thrusts (Fig. 2). To control the depositional age of the sediments, samples were taken in the vicinity of sites with known mammal ages and magneto-polarity based chronologies (Schlunegger et al., 1996; Strunck and Matter, 2002) wherever possible.

In the sampling area, mapping shows that the litho-tectonic architecture of the Subalpine Molasse contrasts between both sides of Lake Thun (Fig. 2). On the eastern side, the basin is made up of amalgamated conglomerates and a relatively large spacing between the major thrust faults, while the tectonic style of the Subalpine Molasse to the west of Lake Thun is characterized by more evenly distributed thrust sheets made up of alternated sandstone and mudstone beds. The same pattern

15 can be found along strike where the distribution pattern of conglomerates, sandstones, and mudstones tends to condition the location and the spacing of thrust faults. We thus compiled more details about the geological architecture of the proximal Molasse from published geological maps (Landesgeologie, 2005) and use available tectonic sections (Sommaruga et al., 2012) to illustrate the related tectonic style.

\section{2 (U-Th-Sm)/He (AHe) thermochronology and thermal modeling}

20 We determined the most recent exhumation history of the Subalpine Molasse through AHe dating. This method is based on the $\alpha$-decay of ${ }^{238} \mathrm{U},{ }^{235} \mathrm{U},{ }^{232} \mathrm{Th}$ and ${ }^{147} \mathrm{Sm}$ isotopes, and the retention of its radiogenic product ${ }^{4} \mathrm{He}$ in the crystal lattice below a certain temperature (e.g., Farley, 2002). Diffusive loss of ${ }^{4} \mathrm{He}$ in the lattice depends on the grain size, shape, chemical composition, distribution of the mother isotopes, radiation damage density, as well as the time-temperature evolution of the crystal (Farley, 2002; Wolf et al., 1996). Consequently, AHe ages can provide estimates when the mineral passed through

25 the diffusion-sensitive temperature interval between ca. $80^{\circ} \mathrm{C}$ and $40^{\circ} \mathrm{C}$ (Wolf et al., 1996), which is referred to as the partial retention zone (PRZ). Hence, this technology allows constraining the tectono-thermal history of the studied rocks in the uppermost few kilometers of Earth's crust. Detrital apatite grains deposited in sedimentary basins primarily carry a cooling history of the hinterland at the time of erosion. However, subsequent burial due to sedimentation or tectonic loading may reheat the detrital grains to temperatures above the closure temperature, thereby resetting the chronometer. Subsequent exhumation will chronicle the basin's exhumation, whereas grains that have not been reset during the basin's burial history 
Solid Earth Discuss., https://doi.org/10.5194/se-2019-56

Manuscript under review for journal Solid Earth

Discussion started: 20 March 2019

(c) Author(s) 2019. CC BY 4.0 License.

still carry a signal of older cooling events. Consequently, the relation between cooling age and stratigraphic age may provide estimates on the burial as well as the exhumation history (e.g., Reiners and Brandon, 2006).

We used a combination of standard techniques for the separation of apatite minerals, which particularly includes electrodynamic disaggregation, and magnetic and heavy liquid separation. Single crystals were handpicked under a binocular and checked for inclusions and imperfections under an optical microscope with cross-polarized light (more information on the mineral separation techniques and picking criteria are given in Text A1 in the supplementary material). Helium extraction and measurement of parent isotope contents has been conducted at the GÖochron laboratories of University of Göttingen. Raw ages were corrected for $\alpha$-ejection (Table 1). We measured four to eight single grain ages per sample and calculated average ages using the unweighted arithmetic mean for completely reset samples. We excluded single grain ages

10 for subsequent geological interpretation based on the following criteria (Table 1): (i) high analytical errors ( $>10 \%$ ), (ii) very low U-content $(<10 \mathrm{ppm})$, (iii) a substantial amount of $\mathrm{He}$ on the first re-extract $(>4 \%)$, or erroneous old ages stemming most likely from U-Th rich mineral inclusions which produce parentless He. For the latter case, we plotted the He content versus the present-day He production rate in order to detect these ages (for details see Vermeesch, 2008).

We constrained the thermal histories of the sampled sediments (Fig. 3) by modeling of the AHe age data with the HeFTy 15 software (Ketcham, 2005). We gave the algorithm a maximum degree of freedom. Model constraints included the age of sedimentation, the paleo-temperature (Mosbrugger et al., 2005), the present-day annual average temperature, and maximum post-depositional heating rates inferred from maximum sedimentation rates (Schlunegger and Norton, 2015) and a paleogeothermal gradient of $28^{\circ} \mathrm{C} / \mathrm{km}$ (Schegg and Leu, 1998).

\section{Results}

\subsection{AHe age data}

The samples SM-7 and SM-16 from the Plateau Molasse show a wide spread in AHe ages, indicating a partially exhumed fossil PRZ. Hence, they did not experience enough post-depositional heating for a full reset of the thermochronometer (Fig. $2 \mathrm{~b}$ and Table 1). All other samples show single grain ages reproducing within error. Ages are significantly younger than the corresponding depositional ages and are thus considered to represent completely reset ages (fully exhumed fossil PRZ), hence inferring substantial post-depositional burial and heating.

Average ages for completely reset samples range from $6.0 \pm 0.4 \mathrm{Ma}$ to $10.8 \pm 0.6 \mathrm{Ma}$ (Fig. 2b and Table 1). All samples from the Subalpine Molasse show post-depositional burial and heating to $>60^{\circ} \mathrm{C}$ (Fig. 3). Sample SM-7 from the Plateau Molasse did not experience enough post-depositional heating to fully reset the thermochronometer (Fig. 3). Thermal modeling confirms the young exhumation of the Subalpine Molasse between $12 \mathrm{Ma}$ and $5 \mathrm{Ma}$ (Fig. 3). The thermal histories of SM-7 and SM-13 indicate an exhumation signal of the Plateau Molasse at ca. 10 Ma. 
Solid Earth Discuss., https://doi.org/10.5194/se-2019-56

Manuscript under review for journal Solid Earth

Discussion started: 20 March 2019

(c) Author(s) 2019. CC BY 4.0 License.

Samples SM-8, SM-11 and SM-15 were collected from the same tectonic sliver (Figs. 2a and 4), and corresponding average ages of $6.0 \pm 0.4 \mathrm{Ma}, 6.6 \pm 0.4 \mathrm{Ma}$ and $6.1 \pm 0.4 \mathrm{Ma}$ reproduce well within error. A jump of average ages occurs to the adjacent tectonic slivers and the Plateau Molasse in the north, where samples SM-12, SM-13, and SM-14 yield average ages of $9.2 \pm 1 \mathrm{Ma}, 8.9 \pm 0.7 \mathrm{Ma}$, and $10.8 \pm 0.6 \mathrm{Ma}$, respectively, thus also reproducing within error. This pattern is also

5 reproduced by the modeled thermal histories, where a jump in exhumation ages across tectonic boundaries is recognized (Fig. 3). In the western area, the average ages do not show such a close correlation with the tectonic position (Figs. 2a and 4). However, the thermal models for samples SM-5 and SM-6 indicate younger cooling than for samples SM-4 and SM-7 (Fig. 3), thus suggesting a tectonic control on exhumation.

\subsection{Late Miocene shortening estimates}

10 Based on published restored cross-sections (Burkhard and Sommaruga, 1998; von Hagke et al., 2014; Ortner et al., 2015), balanced maps (Philippe et al., 1996), thermochronological age data (von Hagke et al., 2012, 2014), and own cross-section restorations, we estimated the amount of late Miocene horizontal shortening of the Subalpine Molasse and the Jura FTB along the entire Central Alps (Fig. 5b). Post-12 Ma horizontal shortening in the Jura FTB decreases from a maximum of ca. $32 \mathrm{~km}$ in the west to $0 \mathrm{~km}$ at the eastern tip (Philippe et al., 1996). Contrariwise, minimum horizontal shortening in the

15 Subalpine Molasse increases from ca. $10 \mathrm{~km}$ in the west to ca. $20 \mathrm{~km}$ farther east, before decreasing again to below $1 \mathrm{~km}$ in the Eastern Alps (Burkhard and Sommaruga, 1998; von Hagke et al., 2012, 2014; Hinsch, 2013; Ortner et al., 2015). These values do not account for shortening taken up by the frontal triangle zone between ca. 20 Ma and $12 \mathrm{Ma}$ (von Hagke et al., 2014; Kempf et al., 1999; Ortner et al., 2015). Despite the uncertainty in the shortening estimates within the Subalpine Molasse (Burkhard and Sommaruga, 1998; von Hagke and Malz, 2018; Ortner et al., 2015), we observe that late Miocene

20 cumulative shortening of the Subalpine Molasse and the Jura FTB decreases constantly from the west to the east from $>30$ $\mathrm{km}$ near Geneva to $20 \mathrm{~km}$ near Lake Constance, before finally decreasing to $<1 \mathrm{~km}$ near Salzburg (12.8 E; Fig. $5 \mathrm{~b})$. It is thus noteworthy that late Miocene shortening in the foreland does not correlate with the peaks of high-uplift domains of the ECMs in the hinterland (Fig. 5c).

\section{Discussion}

\section{5.1 Downscaling: Local-scale stratigraphic architecture conditioning the pattern of strain release}

In the sampling area, mapping discloses clear along-strike differences in the litho-tectonic architecture of the Subalpine Molasse (Fig. 2). The sediments are thrusted northwestward along SW-NE striking thrusts. East of the Aare valley, a back thrust emerges to the surface and forms a frontal triangle zone (Figs. 2 and 4), a structure which is also known from parts of the Subalpine Molasse farther east (Fig. 6; e.g. Berge and Veal, 2005; Müller et al., 1988; Schuller et al., 2015; Sommaruga 30 et al., 2012; Stäuble and Pfiffner, 1991). The Aare valley, running across the study area, is characterized by a low relief and 
Solid Earth Discuss., https://doi.org/10.5194/se-2019-56

Manuscript under review for journal Solid Earth

Discussion started: 20 March 2019

(c) Author(s) 2019. CC BY 4.0 License.

is filled by $>100$ m-thick Quaternary deposits (Fig. 4; Dürst Stucki et al., 2010). Accordingly, the structural configuration of this part of the study area is only poorly resolved. However, the structures of the Subalpine Molasse change abruptly across the Aare valley (Figs. 2 and 4), as has been described by many authors (Beck, 1945; Blau, 1966; Haus, 1937; Pfiffner, 2011; Rutsch, 1947; Vollmayr, 1992). Based on this observation and under the consideration of a few interpreted reflection seismic

5 lines, the presence of a possible syntectonic strike-slip fault zone running along the valley axis has been proposed (Mock and Herwegh, 2017; Pfiffner, 2011; Vollmayr, 1992). The presence of such a fault is however speculative due to the low resolution of the seismic data. An alternative explanation for the sudden along-strike change in the tectonic architecture has first been mentioned by Rutsch (1947). He reported that the change from a mainly conglomeratic (east) to a sand- and mudstone dominated (west) lithofacies coincides with an increase in folding intensity along the frontmost anticline

10 (Falkenfluh anticline; Fig. 2a). Indeed, while conglomerates are the dominant lithofacies in the eastern part of the study area, they are vastly absent west of the Aare valley, where mainly alternating sequences of sandstones and mudstones are outcropping (Figs. 2 and 6; Landesgeologie, 2005). The distribution of mechanically different lithologies seems to control the pattern of strain release. While east of the Aare valley, the mechanically stronger thick conglomeratic sequences deform en-bloc and thrusts are concentrated in narrow bands following mechanically weak zones of sand- and mudstones, strain is

15 released much more distributed along more closely spaced thrusts in the western part of the study area. The pronounced mechanical contrast between conglomerates and sand-/mudstones is also manifested in well-defined and constant AHe ages of ca. $6 \mathrm{Ma}$ for the large tectonic slice of amalgamated conglomerates east of the Aare valley (Figs. 2 and 4). AHe ages west of the Aare valley, however, chronicle a more evenly distributed deformation and exhumation pattern, which is most likely conditioned and thus controlled by the low mechanical contrast of the corresponding lithologies.

20 The observation that along-strike variations in the stratigraphic architecture lead to complex patterns of strain partitioning is not unique to our sample area, but can be made also in the Mont Pèlerin, the Rigi, or the Hörnli region in western, central, and eastern Switzerland, respectively (Fig. 6). In particular, the lithological control on the strain release and exhumation pattern is well observed in the Rigi area (profile 3 in Fig. 6; Sommaruga et al., 2012). The thick conglomerate sequence of the Rigi thrust sheet was (re-)activated en-bloc at ca. $5 \mathrm{Ma}$, while the adjacent sand- and mudstone dominated part to the north experienced a period of thrusting at ca. 9 Ma along evenly spaced faults (von Hagke et al., 2012). Similar dependencies between the style of deformation and lateral changes in lithology have also been described for the Subalpine Molasse in southern Germany and western Austria (Ortner et al., 2015).

\subsection{Upscaling: Implications for late orogenic processes at the scale of the Alps}

Classically, thrusting in the Subalpine Molasse and the Jura FTB has been kinematically and spatio-temporally related to the 30 uplift and exhumation of the ECMs (e.g., Aar Massif; Burkhard, 1990), and to the propagation of the deformation front towards the foreland. However, it has also been reported that the proximal foreland basin east of the easternmost ECM, the Aar Massif, has been subject to post-12 Ma thrusting and horizontal shortening (Figs. 5a and 5b; Ortner et al., 2015). Our 
Solid Earth Discuss., https://doi.org/10.5194/se-2019-56

Manuscript under review for journal Solid Earth

Discussion started: 20 March 2019

(c) Author(s) 2019. CC BY 4.0 License.

AHe age data from the Subalpine Molasse (Figs. 2, 3, and 4) fit with AHe ages farther east (von Hagke et al., 2012, 2014) and chronicle the occurrence of thrusting and exhumation of the Subalpine Molasse between $12 \mathrm{Ma}$ and $4 \mathrm{Ma}$ (Fig. 5a). This happened coeval to the main deformation phase in the Jura FTB, which lasted from ca. 12-4 Ma (e.g. Becker, 2000). Similar ages constrained from seismic interpretation have been reported for the easternmost part of the Subalpine Molasse (Fig. 5a;

5 Ortner et al., 2015), and based on stratigraphic data, Haus (1935) inferred already in 1935 that the Subalpine Molasse of Central Switzerland was subject to major thrusting in late Miocene times. Since the youngest AHe ages are associated with internal tectonic slices of the Subalpine Molasse (Figs. 2, 3, and 4), we can infer the occurrence of break-back thrusting, a characteristic feature, which has been confirmed along the entire Subalpine Molasse of the Central Alps based on thermochronological data and cross section restoration (von Hagke et al., 2012, 2014; Ortner et al., 2015; Schuller et al.,

10 2015), but has been argued for as early as the 1930s (Haus, 1935, 1937). The break-back thrusts are supposedly younger than the development of the frontal triangle zone, which formed the active northern deformation front from ca. 20-12 Ma (von Hagke et al., 2014; Ortner et al., 2015). Furthermore, our AHe ages from the Plateau Molasse record a partially exhumed PRZ (Figs. 2, 3, and 4) and thus corroborate the occurrence of substantial exhumation of the flat-lying Plateau Molasse (Cederbom et al., 2011; von Hagke et al., 2012), indicating a large wavelength exhumation signal.

15 The rapid change from pre-12 Ma vertical tectonics in the core of the Alps (Herwegh et al., 2017; Hurford, 1986; Schmid et al., 1996), with the triangle zone in the Subalpine Molasse acting as a stationary deformation front from ca. 20-12 Ma (von Hagke et al., 2014; Ortner et al., 2015), to post-12 Ma orogen-scale horizontal tectonics, accompanied by lateral orogenic growth, cannot be explained by a classical model of continent-continent collision and continuous foreland propagation of the orogenic wedge. In the following, we discuss the observed exhumation pattern along the Subalpine Molasse (Fig. 5a) in the

20 context of the post-35 Ma tectonic evolution of the Alpine orogen and argue for a deep-driver to control the transition from dominantly vertical to horizontal tectonics, associated with widespread tectonic activity in the foreland and lateral orogenic growth.

During the Alpine orogeny, convergence rates between the Adriatic and European continental plates decreased when the positively buoyant European continental crust started to enter the subduction zone (Fig. 7b; Handy et al., 2010; Schmid et al.,

25 1996) and when delamination and wedging of European continental crust was initiated (Schmid et al., 1996). Large slab pull forces exerted by the negatively buoyant oceanic lithospheric slab induced extensional forces within the subducting plate, which led to necking and eventually to slab breakoff (Davies and von Blanckenburg, 1995). Subsequent slab unloading caused strong uplift and backthrusting along the Insubric Line (Berger et al., 2011; Hurford, 1986; Schmid et al., 1996). The delaminated and thus dense European mantle slab, which was still attached to the foreland plate, continued to roll back

30 (Kissling, 2008; Kissling and Schlunegger, 2018), with the consequence of slab steepening and northward migration of the slab's hinge. This forced new crustal material to enter the subduction system and to become accreted to the crustal root as evidenced by the emplacement of the Helvetic nappes (Fig. 7c) and basal accretion of middle crustal material (Fry et al., 2010). Pro-wedge directed migration of the slab's hinge resulted in a northward propagation of the northern margin of the 
Solid Earth Discuss., https://doi.org/10.5194/se-2019-56

Manuscript under review for journal Solid Earth

Discussion started: 20 March 2019

(c) Author(s) 2019. CC BY 4.0 License.

Molasse Basin until ca. 20 Ma (Fig. 7a). Thereafter, plate convergence rates seemed to decrease noticeably (Fig. 7b; Handy et al., 2010; Schmid et al., 1996). At this stage, pro-wedge widening of the Molasse Basin came to a relative halt, while the proximal part of the basin kept subsiding by additional 2-3 km (Fig. 7a; Burkhard and Sommaruga, 1998; Schlunegger and Kissling, 2015). This phase was also associated with the period of vertical tectonics of the ECMs, i.e. their rise along steeply 5 dipping shear zones between ca. 20 Ma and 12 Ma (Herwegh et al., 2017; Wehrens et al., 2017), while the northern deformation front remained stationary in the Subalpine Molasse (Fig. 7c; Burkhard and Sommaruga, 1998; von Hagke et al., 2014; Ortner et al., 2015).

During middle to late Miocene times, the Alps underwent a major change from dominantly vertical to horizontal tectonics. This is also witnessed by the supersession of the vertical extrusion of the ECMs by north-directed thrusting along shallow

10 SE-dipping shear zones (Fig. 7c; Herwegh et al., 2017). At the same time, deformation propagated 50-90 km to the north into the Jura FTB (Becker, 2000) and the Subalpine Molasse experienced break-back thrusting and thrust reactivation along the entire Central Alps (Figs. 5a and 7c), which we date with 12-4 Ma using the new chronological constraints presented here and reported from farther east (von Hagke et al., 2012, 2014). The occurrence of late Miocene thrusting has also been reported for the foreland of the Western Alps (Schwartz et al., 2017). In the Southern Alps, deformation propagated ca. 50

$15 \mathrm{~km}$ southward between ca. $15 \mathrm{Ma}$ and $7 \mathrm{Ma}$ (Schmid et al., 1996; Schönborn, 1992). Because the tectonically driven exhumation signal between $12 \mathrm{Ma}$ and $4 \mathrm{Ma}$ is not unique to the forelands of the ECMs and late Miocene shortening estimates in the North Alpine foreland do not correlate spatially with the high-uplift domains of the ECMs (Fig. 5), we suggest that although kinematically linked, the late Miocene foreland deformation is not a consequence of uplift and exhumation of the ECMs, as previous work suggested (Burkhard, 1990; Burkhard and Sommaruga, 1998; Pfiffner et al.,

20 1997). It rather reflects the response to the change of a geodynamic driving force operating at a larger scale, situated at deeper crustal levels and encompassing the entire Central Alps, as far east as $12.8^{\circ} \mathrm{E}$ (near Salzburg). This deep-seated driving force is recorded by a decrease in the amount of shortening from $>30 \mathrm{~km}$ near Lake Geneva, to ca. $20 \mathrm{~km}$ near Lake Constance, and finally to $>1 \mathrm{~km}$ near Salzburg. We are not able to precisely allocate and to identify the source and the nature of this signal, but we expect that ongoing seismo-tomographic investigations will disclose further details to constrain the underlying driving mechanisms (Hetényi et al., 2018).

Although we lack the required data to constrain the geodynamic processes responsible for the late phase of shortening in the Molasse, we are able to constrain the timing of this event to 12-4 Ma. In addition, this work shows that low-temperature thermochronological data yield an improved understanding of the chronology of orogenic processes where the late orogenic stage of a mountain belt may be characterized by a complex pattern of stress release conditioned by site-specific stratigraphic

30 and thus lithological conditions at the local scale, and by a change from vertical to horizontal tectonics at the larger scale including the entire Central Alps. 
Solid Earth Discuss., https://doi.org/10.5194/se-2019-56

Manuscript under review for journal Solid Earth

Discussion started: 20 March 2019

(c) Author(s) 2019. CC BY 4.0 License.

\section{Conclusions}

In this paper, we present new low-temperature thermochronological age data from the Subalpine Molasse of the Central European Alps. By comparing our results to published age and stratigraphic data along-strike the Central Alps we conclude that:

- (U-Th-Sm)/He ages along the Subalpine Molasse of the Central Alps are consistently between 12-4 Ma and can be assigned to at least two tectonic pulses at ca. 10 and 6 Ma.

- The pattern of strain release is strongly conditioned by the local-scale mechanical stratigraphy, since the locus of deformation depends on the distribution of mechanically weak (sand- and mudstones) and strong (conglomerates) lithologies.

- Despite the along-strike highly non-cylindrical hinterland exhumation history and architecture, the late Miocene tectonic signal recorded in the Subalpine Molasse is remarkably constant along the entire Central Alps (from Lake Geneva to Salzburg).

Hence, we observe that the deformation style during late Miocene thrusting of the Subalpine Molasse is masked by local variations in the stratigraphic architecture. However, the overall tectonic signal, though decreasing in intensity from the west

15 to the east, is very consistent in terms of timing and kinematics along-strike the entire Central Alps. This consistent signal might be the result of a lithospheric driving force acting at a large wavelength and leading to a prominent change in the macro-tectonic regime of the Central Alps at ca. $12 \mathrm{Ma}$, from dominantly vertical to horizontal tectonics.

\section{Appendix A: Apatite separation and picking}

To release the apatite crystals from the rock samples, we used the electrodynamic disaggregation technique (selFrag). This method exposes the rock specimen to a high voltage pulse and fractures it along its grain boundaries. As opposed to separation using a jaw crusher, this method is less time consuming and the rock is disintegrated along the grain boundaries (Giese et al., 2010). This ensures individual grains are less prone to damaging during processing.

To prepare the samples for electrodynamic disaggregation, they had to be crushed into fist-sized pieces by hand using a hammer. This was necessary due to the limiting dimensions of the processing vessel of the selFrag. For releasing the individual grains, we applied a frequency of $3 \mathrm{~Hz}$ and electric potentials of 130-150 kV, depending on the hardness of the rock. For every sample, the electrode distance was incrementally reduced in $5 \mathrm{~mm}$ steps from a maximum of $40 \mathrm{~mm}$ to a minimum of $15 \mathrm{~mm}$. Per step, a minimum of 20 pulses was applied to ensure full release of the individual grains. It has been shown that the influence of diffusive loss of ${ }^{4} \mathrm{He}$ due to the plasma channel hitting the apatite crystal is negligible, and (U$\mathrm{Th}-\mathrm{Sm}$ )/He (AHe) ages from samples separated with electrodynamic disaggregation are indistinguishable from AHe ages measured on apatites released with mechanical techniques (Giese et al., 2010). 
Solid Earth Discuss., https://doi.org/10.5194/se-2019-56

Manuscript under review for journal Solid Earth

Discussion started: 20 March 2019

(c) Author(s) 2019. CC BY 4.0 License.

Apatite crystals were concentrated using standard rock separation techniques. First, the grain size fraction of $64-250 \mu \mathrm{m}$, which is suitable for AHe dating, was separated using disposable sieving meshes. To remove magnetic minerals from the sieved sample fraction, we used a Frantz magnetic separator at $0.5 \mathrm{~A}$ and $1.2 \mathrm{~A}$. To concentrate apatite from the remaining grains, we used lithium-based tungstate $\left(\rho=2.81 \mathrm{~g} \mathrm{~cm}^{-3}\right)$ as heavy liquid for density separation of the heavy minerals. On

5 average, we had to process ca. $100 \mathrm{~g}$ of sample material to acquire enough heavy minerals. The heavy mineral fraction has been thoroughly rinsed with deionized water and then dried at $30^{\circ} \mathrm{C}$.

Apatites have been hand-picked under a binocular and checked for inclusions and imperfections under an optical microscope with cross-polarized light. Wherever possible, we selected euhedral, intact, and inclusion free grains with a minimum width of $60 \mu \mathrm{m}$. However, as the grains are detrital, partly grains with rough surfaces or tiny fluid inclusions had to be picked. This

10 may result in larger error bars or even grain ages that do not yield a geologically meaningful age. These ages were excluded (see section 3.2 and Table 1).

\section{Data availability}

The research data is enclosed in this paper and can be freely accessed.

\section{Author contribution}

15 SM designed the study with support from MH, FS, and CvH. FS and MH assisted SM during sampling in the field. SM carried out mineral separation and picked the apatite crystals. ID carried out the helium extraction and the ICP-MS measurements at University of Göttingen. $\mathrm{CvH}$ and ID assisted in analyzing and interpreting the apatite (U-Th-Sm)/He ages. SM prepared the manuscript, with contributions from all co-authors.

\section{Competing interests}

20 The authors declare that they have no conflict of interest.

\section{Acknowledgements}

We thank Judith Dunkl (Göttingen) for assisting in the selection of apatite crystals, Pierre Valla (Bern) for discussions on the AHe ages and the thermal models, and Edi Kissling (Zurich) for his insights on lithospheric scale processes. Additional information of the data can be found in the supplementary material. The study was funded by the Swiss Geological Survey

25 of the Federal Office of Topography (swisstopo) as part of the GeoMol CH project. We acknowledge the use of the Move Software Suite (used for Figure 4) granted by Midland Valley’s Academic Software Initiative. 
Solid Earth Discuss., https://doi.org/10.5194/se-2019-56

Manuscript under review for journal Solid Earth

Discussion started: 20 March 2019

(c) Author(s) 2019. CC BY 4.0 License.

\section{References}

Allen, P. A., Crampton, S. L. and Sinclair, H. D.: The inception and early evolution of the North Alpine Foreland Basin, Switzerland, Basin Res., 3(3), 143-163, doi:10.1111/j.1365-2117.1991.tb00124.x, 1991.

Aubert, D.: Sur l'existence d'une ride de plissement oligocène dans le Jura vaudois, Bull. la Société Neuchâteloise des Sci. 5 Nat., 81, 47-54, 1958.

Baran, R., Friedrich, A. M. and Schlunegger, F.: The late Miocene to Holocene erosion pattern of the Alpine foreland basin reflects Eurasian slab unloading beneath the western Alps rather than global climate change, Lithosphere, 6(2), 124-131, doi:10.1130/L307.1, 2014.

Beck, P.: Über den Mechanismus der subalpinen Molassetektonik, Eclogae Geol. Helv., 38(2), 353-368, 1945.

10 Becker, A.: The Jura Mountains - an active foreland fold-and-thrust belt?, Tectonophysics, 321(4), 381-406, doi:10.1016/S0040-1951(00)00089-5, 2000.

Berge, T. B. and Veal, S. L.: Structure of the Alpine foreland, Tectonics, 24(5), TC5011, doi:10.1029/2003TC001588, 2005.

Berger, A., Schmid, S. M., Engi, M., Bousquet, R. and Wiederkehr, M.: Mechanisms of mass and heat transport during Barrovian metamorphism: A discussion based on field evidence from the Central Alps (Switzerland/northern Italy),

15 Tectonics, 30(1), TC1007, doi:10.1029/2009TC002622, 2011.

Blau, R. V.: Molasse und Flysch im östlichen Gurnigelgebiet (Kt. Bern), Beiträge zur Geol. Karte der Schweiz, NF 125, 151 pp., 1966.

Burkhard, M.: Aspects of the large-scale Miocene deformation in the most external part of the Swiss Alps (Subalpine Molasse to Jura fold belt), Eclogae Geol. Helv., 83(3), 559-583, 1990.

20 Burkhard, M. and Sommaruga, A.: Evolution of the western Swiss Molasse basin: structural relations with the Alps and the Jura belt, Geol. Soc. London, Spec. Publ., 134(1), 279-298, doi:10.1144/GSL.SP.1998.134.01.13, 1998.

Buxtorf, A.: Prognosen und Befunde beim Hauensteinbasis- und Grenchenbergtunnel und die Bedeutung der letzteren für die Geologie des Juragebirges, Verhandlungen der Naturforschenden Gesesellschaft Basel, 27, 184-254, 1916.

Cederbom, C. E., Sinclair, H. D., Schlunegger, F. and Rahn, M. K.: Climate-induced rebound and exhumation of the 25 European Alps, Geology, 32(8), 709, doi:10.1130/g20491.1, 2004.

Cederbom, C. E., van der Beek, P., Schlunegger, F., Sinclair, H. D. and Oncken, O.: Rapid extensive erosion of the North Alpine foreland basin at 5-4 Ma, Basin Res., 23(5), 528-550, doi:10.1111/j.1365-2117.2011.00501.x, 2011.

Champagnac, J.-D., Molnar, P., Anderson, R. S., Sue, C. and Delacou, B.: Quaternary erosion-induced isostatic rebound in the western Alps, Geology, 35(3), 195, doi:10.1130/G23053A.1, 2007. 
Solid Earth Discuss., https://doi.org/10.5194/se-2019-56

Manuscript under review for journal Solid Earth

Discussion started: 20 March 2019

(c) Author(s) 2019. CC BY 4.0 License.

Chemenda, A. I., Burg, J. P. and Mattauer, M.: Evolutionary model of the Himalaya-Tibet system: Geopoem based on new modelling, geological and geophysical data, Earth Planet. Sci. Lett., 174(3-4), 397-409, doi:10.1016/S0012$821 X(99) 00277-0,2000$.

Davies, J. H. and von Blanckenburg, F.: Slab breakoff: A model of lithosphere detachment and its test in the magmatism and deformation of collisional orogens, Earth Planet. Sci. Lett., 129(1-4), 85-102, doi:10.1016/0012-821X(94)00237-S, 1995.

DeCelles, P. G. and Giles, K. A.: Foreland basin systems, Basin Res., 8(2), 105-123, doi:10.1046/j.13652117.1996.01491.x, 1996.

Dürst Stucki, M., Reber, R. and Schlunegger, F.: Subglacial tunnel valleys in the Alpine foreland: an example from Bern, Switzerland, Swiss J. Geosci., 103(3), 363-374, doi:10.1007/s00015-010-0042-0, 2010.

10 Farley, K. A.: (U-Th)/He Dating: Techniques, Calibrations, and Applications, Rev. Mineral. Geochemistry, 47(1), 819-844, doi:10.2138/rmg.2002.47.18, 2002.

Farley, K. A., Wolf, R. A. and Silver, L. T.: The effects of long alpha-stopping distances on (U-Th)/He ages, Geochim. Cosmochim. Acta, 60(21), 4223-4229, doi:10.1016/S0016-7037(96)00193-7, 1996.

Fry, B., Deschamps, F., Kissling, E., Stehly, L. and Giardini, D.: Layered azimuthal anisotropy of Rayleigh wave phase 15 velocities in the European Alpine lithosphere inferred from ambient noise, Earth Planet. Sci. Lett., 297(1-2), 95-102, doi:10.1016/j.epsl.2010.06.008, 2010.

Fuchs, W.: Gedanken zur Tektogenese der nördlichen Molasse zwischen Rhone und March, Jahrb. der Geol. Bundesanstalt, 119(2), 207-249, 1976.

Ganss, O. and Schmidt-Thomé, P.: Die gefaltete Molasse am Alpenrand zwischen Bodensee und Salzach, Zeitschrift der Dtsch. Geol. Gesellschaft, 105, 402-495, 1953.

Garefalakis, P. and Schlunegger, F.: Link between concentrations of sediment flux and deep crustal processes beneath the European Alps, Sci. Rep., 8(1), 183, doi:10.1038/s41598-017-17182-8, 2018.

Giamboni, M., Ustaszewski, K., Schmid, S. M., Schumacher, M. E. and Wetzel, A.: Plio-Pleistocene transpressional reactivation of Paleozoic and Paleogene structures in the Rhine-Bresse transform zone (northern Switzerland and eastern 25 France), Int. J. Earth Sci., 93(2), 207-223, doi:10.1007/s00531-003-0375-2, 2004.

Giese, J., Seward, D., Stuart, F. M., Wüthrich, E., Gnos, E., Kurz, D., Eggenberger, U. and Schreurs, G.: Electrodynamic Disaggregation: Does it Affect Apatite Fission-Track and (U-Th)/He Analyses?, Geostand. Geoanalytical Res., 34(1), 39-48, doi:10.1111/j.1751-908X.2009.00013.x, 2010.

Glotzbach, C., Reinecker, J., Danišík, M., Rahn, M. K., Frisch, W. and Spiegel, C.: Thermal history of the central Gotthard 
Solid Earth Discuss., https://doi.org/10.5194/se-2019-56

Manuscript under review for journal Solid Earth

Discussion started: 20 March 2019

(c) Author(s) 2019. CC BY 4.0 License.

and Aar massifs, European Alps: Evidence for steady state, long-term exhumation, J. Geophys. Res., 115, F03017, doi:10.1029/2009JF001304, 2010.

Guellec, S., Mugnier, J.-L., Tardy, M. and Roure, F.: Neogene evolution of the western Alpine foreland in the light of ECORS data and balanced cross-section, in Deep structure of the Alps, Mém. Soc. géol. suisse, vol. 1, edited by F. Roure, P.

5 Heitzmann, and R. Polino, pp. 165-184, Société Geologique Suisse, Zürich., 1990.

von Hagke, C. and Malz, A.: Triangle zones - Geometry, kinematics, mechanics, and the need for appreciation of uncertainties, Earth-Science Rev., 177(November 2017), 24-42, doi:10.1016/j.earscirev.2017.11.003, 2018.

von Hagke, C., Cederbom, C. E., Oncken, O., Stöckli, D. F., Rahn, M. K. and Schlunegger, F.: Linking the northern Alps with their foreland: The latest exhumation history resolved by low-temperature thermochronology, Tectonics, 31(5),

10 TC5010, doi:10.1029/2011TC003078, 2012.

von Hagke, C., Oncken, O., Ortner, H., Cederbom, C. E. and Aichholzer, S.: Late Miocene to present deformation and erosion of the Central Alps — Evidence for steady state mountain building from thermokinematic data, Tectonophysics, 632, 250-260, doi:10.1016/j.tecto.2014.06.021, 2014.

Haldemann, E. G., Haus, H. A., Holliger, A., Liechti, W., Rutsch, R. F. and della Valle, G.: Geological Atlas of Switzerland

15 1:25000, Map sheet Eggiwil (LK 1188), Federal Office of Topography swisstopo, Wabern, Switzerland., 1980.

Handy, M. R., Schmid, S. M., Bousquet, R., Kissling, E. and Bernoulli, D.: Reconciling plate-tectonic reconstructions of Alpine Tethys with the geological-geophysical record of spreading and subduction in the Alps, Earth-Science Rev., 102(34), 121-158, doi:10.1016/j.earscirev.2010.06.002, 2010.

Haus, H.: Über alte Erosionserscheinungen am Südrand der miocaenen Nagelfluh des oberen Emmentales und deren Bedeutung für die Tektonik des Alpenrandes, Eclogae Geol. Helv., 28(2), 667-677, 1935.

Haus, H.: Geologie der Gegend von Schangnau im oberen Emmental (Kanton Bern): ein Beitrag zur Stratigraphie und Tektonik der subalpinen Molasse und des Alpenrandes, Beiträge zur Geol. Karte der Schweiz, NF 75, 106 pp., 1937.

Herwegh, M., Berger, A., Baumberger, R., Wehrens, P. and Kissling, E.: Large-Scale Crustal-Block-Extrusion During Late Alpine Collision, Sci. Rep., 7, 413, doi:10.1038/s41598-017-00440-0, 2017.

25 Hetényi, G., Molinari, I., Clinton, J., Bokelmann, G., Bondár, I., Crawford, W. C., Dessa, J.-X., Doubre, C., Friederich, W., Fuchs, F., Giardini, D., Gráczer, Z., Handy, M. R., Herak, M., Jia, Y., Kissling, E., Kopp, H., Korn, M., Margheriti, L., Meier, T., Mucciarelli, M., Paul, A., Pesaresi, D., Piromallo, C., Plenefisch, T., Plomerová, J., Ritter, J., Rümpker, G., Šipka, V., Spallarossa, D., Thomas, C., Tilmann, F., Wassermann, J., Weber, M., Wéber, Z., Wesztergom, V. and Živčić, M.: The AlpArray Seismic Network: A Large-Scale European Experiment to Image the Alpine Orogen, Surv. Geophys., 39(5), 100930 1033, doi:10.1007/s10712-018-9472-4, 2018. 
Solid Earth Discuss., https://doi.org/10.5194/se-2019-56

Manuscript under review for journal Solid Earth

Discussion started: 20 March 2019

(c) Author(s) 2019. CC BY 4.0 License.

Hinsch, R.: Laterally varying structure and kinematics of the Molasse fold and thrust belt of the Central Eastern Alps: Implications for exploration, Am. Assoc. Pet. Geol. Bull., 97(10), 1805-1831, doi:1 0.1306/04081312129, 2013.

Homewood, P., Allen, P. A. and Williams, G. D.: Dynamics of the Molasse Basin of Western Switzerland, in Foreland Basins, pp. 199-217, Blackwell Publishing Ltd., Oxford, UK., 1986.

5 Hourigan, J. K., Reiners, P. W. and Brandon, M. T.: U-Th zonation-dependent alpha-ejection in (U-Th)/He chronometry, Geochim. Cosmochim. Acta, 69(13), 3349-3365, doi:10.1016/j.gca.2005.01.024, 2005.

Hurford, A. J.: Cooling and uplift patterns in the Lepontine Alps South Central Switzerland and an age of vertical movement on the Insubric fault line, Contrib. to Mineral. Petrol., 92(4), 413-427, doi:10.1007/BF00374424, 1986.

Jordi, H. A.: Blatt 1188 Eggiwil, Geol. Atlas Schweiz 125 000, Erläut. 75, 2012.

10 Karner, G. D. and Watts, A. B.: Gravity anomalies and flexure of the lithosphere at mountain ranges, J. Geophys. Res. Solid Earth, 88(B12), 10449-10477, doi:10.1029/JB088iB12p10449, 1983.

Kempf, O., Matter, A., Burbank, D. W. and Mange, M.: Depositional and structural evolution of a foreland basin margin in a magnetostratigraphic framework: the eastern Swiss Molasse Basin, Int. J. Earth Sci., 88(2), 253-275, doi:10.1007/s005310050263, 1999.

15 Ketcham, R. A.: Forward and Inverse Modeling of Low-Temperature Thermochronometry Data, Rev. Mineral. Geochemistry, 58(1), 275-314, doi:10.2138/rmg.2005.58.11, 2005.

Kissling, E.: Deep structure and tectonics of the Valais - And the rest of the Alps, Bull. fuer Angew. Geol., 13(2), 3-10, 2008 .

Kissling, E. and Schlunegger, F.: Rollback Orogeny Model for the Evolution of the Swiss Alps, Tectonics, 37(4), 1097-

20 1115, doi:10.1002/2017TC004762, 2018.

Kuhlemann, J. and Kempf, O.: Post-Eocene evolution of the North Alpine Foreland Basin and its response to Alpine tectonics, Sediment. Geol., 152(1-2), 45-78, doi:10.1016/S0037-0738(01)00285-8, 2002.

Landesgeologie: Geological Map of Switzerland 1:500’000, Federal Office of Topography swisstopo, Wabern, Switzerland., 2005.

25 Laubscher, H. P.: Die Fernschubhypothese der Jurafaltung, Eclogae Geol. Helv., 54(1), 221-280, 1961.

Leary, R., Orme, D. A., Laskowski, A. K., DeCelles, P. G., Kapp, P., Carrapa, B. and Dettinger, M.: Along-strike diachroneity in deposition of the Kailas Formation in central southern Tibet: Implications for Indian slab dynamics, Geosphere, 12(4), 1198-1223, doi:10.1130/GES01325.1, 2016.

Liniger, H.: Pliozän und Tektonik des Juragebirges, Eclogae Geol. Helv., 60(2), 407-490, 1967. 
Solid Earth Discuss., https://doi.org/10.5194/se-2019-56

Manuscript under review for journal Solid Earth

Discussion started: 20 March 2019

(c) Author(s) 2019. CC BY 4.0 License.

Lippitsch, R., Kissling, E. and Ansorge, J.: Upper mantle structure beneath the Alpine orogen from high-resolution teleseismic tomography, J. Geophys. Res., 108(B8), 2376, doi:10.1029/2002JB002016, 2003.

Madritsch, H., Schmid, S. M. and Fabbri, O.: Interactions between thin- and thick-skinned tectonics at the northwestern front of the Jura fold-and-thrust belt (eastern France), Tectonics, 27(5), TC5005, doi:10.1029/2008TC002282, 2008.

5 Marschall, I., Deichmann, N. and Marone, F.: Earthquake focal mechanisms and stress orientations in the eastern Swiss Alps, Swiss J. Geosci., 106(1), 79-90, doi:10.1007/s00015-013-0129-5, 2013.

Mazurek, M., Hurford, A. J. and Leu, W.: Unravelling the multi-stage burial history of the Swiss Molasse Basin: integration of apatite fission track, vitrinite reflectance and biomarker isomerisation analysis, Basin Res., 18(1), 27-50, doi:10.1111/j.1365-2117.2006.00286.x, 2006.

10 Mock, S. and Herwegh, M.: Tectonics of the central Swiss Molasse Basin: Post-Miocene transition to incipient thick-skinned tectonics?, Tectonics, 36(9), 1699-1723, doi:10.1002/2017TC004584, 2017.

Molnar, P., England, P. and Martinod, J.: Mantle dynamics, uplift of the Tibetan plateau, and the Indean monsoon, Rev. Geophys., 31(4), 357-396, 1993.

Mosbrugger, V., Utescher, T. and Dilcher, D. L.: Cenozoic continental climatic evolution of Central Europe, Proc. Natl.

15 Acad. Sci., 102(42), 14964-14969, doi:10.1073/pnas.0505267102, 2005.

Müller, M., Nieberding, F. and Wanninger, A.: Tectonic style and pressure distribution at the northern margin of the Alps between Lake Constance and the River Inn, Geol. Rundschau, 77(3), 787-796, doi:10.1007/BF01830185, 1988.

Oncken, O., Hindle, D., Kley, J., Elger, K., Victor, P. and Schemmann, K.: Deformation of the Central Andean Upper Plate System - Facts, Fiction, and Constraints for Plateau Models, in The Andes. Frontiers in Earth Sciences, edited by O.

20 Oncken, G. Chong, G. Franz, P. Giese, H.-J. Götze, V. A. Ramos, M. R. Strecker, and P. Wigger, pp. 3-27, Springer, Berlin Heidelberg., 2006.

Ortner, H., Aichholzer, S., Zerlauth, M., Pilser, R. and Fügenschuh, B.: Geometry, amount, and sequence of thrusting in the Subalpine Molasse of western Austria and southern Germany, European Alps, Tectonics, 34(1), 1-30, doi:10.1002/2014TC003550, 2015.

25 Pfiffner, O. A.: Evolution of the North Alpine Foreland Basin in the Central Alps, in Foreland Basins, edited by P. A. Allen and P. Homewood, pp. 219-228, Blackwell Publishing Ltd., Oxford, UK., 1986.

Pfiffner, O. A.: Geologie der Alpen, 1st ed., Haupt, Bern, Stuttgart, Wien., 2009.

Pfiffner, O. A.: Structural Map of the Helvetic Zone of the Swiss Alps, including Vorarlberg (Austria) and Haute Savoie (France), 1:100 000, edited by Federal Office of Topography swisstopo, Geol. Spec. Map, 128(Explanatory notes), 2011. 
Solid Earth Discuss., https://doi.org/10.5194/se-2019-56

Manuscript under review for journal Solid Earth

Discussion started: 20 March 2019

(c) Author(s) 2019. CC BY 4.0 License.

Pfiffner, O. A.: Basement-involved thin-skinned and thick-skinned tectonics in the Alps, Geol. Mag., 153(5-6), 1085-1109, doi:10.1017/S0016756815001090, 2016.

Pfiffner, O. A., Erard, P. F. and Stäuble, M.: Two cross sections through the Swiss Molasse Basin (lines E4-E6, W1, W7W10), in Deep structure of the Swiss Alps. Results of NRP 20, edited by O. A. Pfiffner, P. Lehner, P. Heitzmann, S. 5 Mueller, and A. Steck, pp. 64-72, Birkhäuser, Basel, Boston, Berlin., 1997.

Philippe, Y., Colletta, B., Deville, E. and Mascle, A.: The Jura fold-and-thrust belt: a kinematic model based on mapbalancing, in Peri Thetys Memoir 2: Structure and prospects of Alpine Basins and Forelands, edited by P. A. Ziegler and F. Horvàth, pp. 235-261, Muséum national d'Histoire naturelle, Paris., 1996.

Pippèrr, M. and Reichenbacher, B.: Late Early Miocene palaeoenvironmental changes in the North Alpine Foreland Basin,

10 Palaeogeogr. Palaeoclimatol. Palaeoecol., 468, 485-502, doi:10.1016/j.palaeo.2017.01.002, 2017.

Reiners, P. W. and Brandon, M. T.: Using Thermochronology to Understand Orogenic Erosion, Annu. Rev. Earth Planet. Sci., 34(1), 419-466, doi:10.1146/annurev.earth.34.031405.125202, 2006.

Rosenberg, C. L. and Berger, A.: On the causes and modes of exhumation and lateral growth of the Alps, Tectonics, 28(6), TC6001, doi:10.1029/2008TC002442, 2009.

15 Rosenberg, C. L. and Kissling, E.: Three-dimensional insight into Central-Alpine collision: Lower-plate or upper-plate indentation?, Geology, 41(12), 1219-1222, doi:10.1130/G34584.1, 2013.

Rosenberg, C. L., Berger, A., Bellahsen, N. and Bousquet, R.: Relating orogen width to shortening, erosion, and exhumation during Alpine collision, Tectonics, 34(6), 1306-1328, doi:10.1002/2014TC003736, 2015.

Rutsch, R.: Molasse und Quartär im Gebiet des Siegfriedblattes Rüeggisberg (Kanton Bern), Beiträge zur Geol. Karte der 20 Schweiz, NF 87, 89 pp., 1947.

Schegg, R. and Leu, W.: Analysis of erosion events and palaeogeothermal gradients in the North Alpine Foreland Basin of Switzerland, Geol. Soc. London, Spec. Publ., 141(1), 137-155, doi:10.1144/GSL.SP.1998.141.01.09, 1998.

Schlunegger, F. and Castelltort, S.: Immediate and delayed signal of slab breakoff in Oligo/Miocene Molasse deposits from the European Alps, Sci. Rep., 6, 31010, doi:10.1038/srep31010, 2016.

25 Schlunegger, F. and Kissling, E.: Slab rollback orogeny in the Alps and evolution of the Swiss Molasse basin, Nat. Commun., 6, 8605, doi:10.1038/ncomms9605, 2015.

Schlunegger, F. and Mosar, J.: The last erosional stage of the Molasse Basin and the Alps, Int. J. Earth Sci., 100(5), 11471162, doi:10.1007/s00531-010-0607-1, 2011.

Schlunegger, F. and Norton, K. P.: Climate vs. tectonics: the competing roles of Late Oligocene warming and Alpine 
Solid Earth Discuss., https://doi.org/10.5194/se-2019-56

Manuscript under review for journal Solid Earth

Discussion started: 20 March 2019

(c) Author(s) 2019. CC BY 4.0 License.

orogenesis in constructing alluvial megafan sequences in the North Alpine foreland basin, Basin Res., 27(2), 230-245, doi:10.1111/bre.12070, 2015.

Schlunegger, F. and Simpson, G.: Possible erosional control on lateral growth of the European Central Alps, Geology, 30(10), 907, doi:10.1130/0091-7613(2002)030<0907:PECOLG>2.0.CO;2, 2002.

5 Schlunegger, F., Matter, A. and Mange, M. A.: Alluvial fan sedimentation and structure of the southern Molasse Basin margin, Lake Thun area, Switzerland, Eclogae Geol. Helv., 86(3), 717-750, 1993.

Schlunegger, F., Burbank, D. W., Matter, A., Engesser, B. and Mödden, C.: Magnetostratigraphic calibration of the Oligocence to Middle Miocene (30-15 Ma) mammal biozones and depositional sequences of the Swiss Molasse Basin, Eclogae Geol. Helv., 89, 753-788, 1996.

10 Schlunegger, F., Matter, A., Burbank, D. W. and Klaper, E. M.: Magnetostratigraphic constraints on relationships between evolution of the central Swiss Molasse basin and Alpine orogenic events, Geol. Soc. Am. Bull., 109(2), 225-241, doi:10.1130/0016-7606(1997)109<0225:MCORBE>2.3.CO;2, 1997.

Schlunegger, F., Rieke-Zapp, D. and Ramseyer, K.: Possible environmental effects on the evolution of the Alps-Molasse Basin system, Swiss J. Geosci., 100(3), 383-405, doi:10.1007/s00015-007-1238-9, 2007.

15 Schlunegger, F., Anspach, O., Bieri, B., Böning, P., Kaufmann, Y., Lahl, K., Lonschinski, M., Mollet, H., Sachse, D., Schubert, C., Stöckli, G. and Zander, I.: Geological Atlas of Switzerland 1:25000, Map sheet Schüpfheim (LK 1169), Federal Office of Topography swisstopo, Wabern, Switzerland., 2016.

Schmid, S. M., Pfiffner, O. A., Froitzheim, N., Schönborn, G. and Kissling, E.: Geophysical-geological transect and tectonic evolution of the Swiss-Italian Alps, Tectonics, 15(5), 1036-1064, doi:10.1029/96TC00433, 1996.

20 Schmid, S. M., Fügenschuh, B., Kissling, E. and Schuster, R.: Tectonic map and overall architecture of the Alpine orogen, Eclogae Geol. Helv., 97(1), 93-117, doi:10.1007/s00015-004-1113-x, 2004.

Schmid, S. M., Kissling, E., Diehl, T., van Hinsbergen, D. J. J. and Molli, G.: Ivrea mantle wedge, arc of the Western Alps, and kinematic evolution of the Alps-Apennines orogenic system, Swiss J. Geosci., 110(2), 581-612, doi:10.1007/s00015016-0237-0, 2017.

25 Schönborn, G.: Alpine tectonics and kinematic models of the central Southern Alps, Mem. di Sci. Geol. Padova, 44, 229393, 1992.

Schuller, V., Frisch, W. and Herzog, U.: Critical taper behaviour and out-of-sequence thrusting on orogenic wedges - an example of the Eastern Alpine Molasse Basin, Terra Nov., 27(3), 231-237, doi:10.1111/ter.12152, 2015.

Schwartz, S., Gautheron, C., Audin, L., Dumont, T., Nomade, J., Barbarand, J., Pinna-Jamme, R. and van der Beek, P.: 
Solid Earth Discuss., https://doi.org/10.5194/se-2019-56

Manuscript under review for journal Solid Earth

Discussion started: 20 March 2019

(c) Author(s) 2019. CC BY 4.0 License.

Foreland exhumation controlled by crustal thickening in the Western Alps, Geology, 45(2), 139-142, doi:10.1130/G38561.1, 2017.

Sinclair, H. D.: Flysch to molasse transition in peripheral foreland basins: The role of the passive margin versus slab breakoff, Geology, 25(12), 1123, doi:10.1130/0091-7613(1997)025<1123:FTMTIP>2.3.CO;2, 1997.

5 Sinclair, H. D. and Allen, P. A.: Vertical versus horizontal motions in the Alpine orogenic wedge: stratigraphic response in the foreland basin, Basin Res., 4(3-4), 215-232, doi:10.1111/j.1365-2117.1992.tb00046.x, 1992.

Sinclair, H. D., Coakley, B. J., Allen, P. A. and Watts, A. B.: Simulation of Foreland Basin Stratigraphy using a diffusion model of mountain belt uplift and erosion: An example from the central Alps, Switzerland, Tectonics, 10(3), 599-620, doi:10.1029/90TC02507, 1991.

10 Sommaruga, A., Eichenberger, U. and Marillier, F.: Seismic Atlas of the Swiss Molasse Basin, edited by the Swiss Geophysical Commission, Matériaux pour la Géologie la Suisse - Géophysique, (44), 2012.

Spiegel, C., Kuhlemann, J., Dunkl, I. and Frisch, W.: Paleogeography and catchment evolution in a mobile orogenic belt: the Central Alps in Oligo-Miocene times, Tectonophysics, 341(1-4), 33-47, doi:10.1016/S0040-1951(01)00187-1, 2001.

Stäuble, M. and Pfiffner, O. A.: Processing, interpretation and modeling of seismic reflection data in the Molasse Basin of eastern Switzerland, Eclogae Geol. Helv., 84(1), 151-175, doi:10.5169/seals-166767, 1991.

Strunck, P. and Matter, A.: Depositional evolution of the western Swiss Molasse, Eclogae Geol. Helv., 95(2), 197-222, doi:http://dx.doi.org/10.5169/seals-168955, 2002.

Sue, C., Delacou, B., Champagnac, J.-D., Allanic, C., Tricart, P. and Burkhard, M.: Extensional neotectonics around the bend of the Western/Central Alps: an overview, Int. J. Earth Sci., 96(6), 1101-1129, doi:10.1007/s00531-007-0181-3, 2007.

20 Ustaszewski, K. and Schmid, S. M.: Latest Pliocene to recent thick-skinned tectonics at the Upper Rhine Graben - Jura Mountains junction, Swiss J. Geosci., 100(2), 293-312, doi:10.1007/s00015-007-1226-0, 2007.

Valla, P. G., van der Beek, P. A., Shuster, D. L., Braun, J., Herman, F., Tassan-Got, L. and Gautheron, C.: Late Neogene exhumation and relief development of the Aar and Aiguilles Rouges massifs (Swiss Alps) from low-temperature thermochronology modeling and $4 \mathrm{He} / 3 \mathrm{He}$ thermochronometry, J. Geophys. Res. Earth Surf., 117, F01004, doi:10.1029/2011JF002043, 2012.

Vermeesch, P.: Three new ways to calculate average (U-Th)/He ages, Chem. Geol., 249(3-4), 339-347, doi:10.1016/j.chemgeo.2008.01.027, 2008.

Vernant, P., Hivert, F., Chery, J., Steer, P., Cattin, R. and Rigo, A.: Erosion-induced isostatic rebound triggers extension in low convergent mountain ranges, Geology, 41(4), 467-470, doi:10.1130/G33942.1, 2013. 
Solid Earth Discuss., https://doi.org/10.5194/se-2019-56

Manuscript under review for journal Solid Earth

Discussion started: 20 March 2019

(c) Author(s) 2019. CC BY 4.0 License.

(c) (1)

Vernon, A. J., van der Beek, P. A., Sinclair, H. D., Persano, C., Foeken, J. and Stuart, F. M.: Variable late Neogene exhumation of the central European Alps: Low-temperature thermochronology from the Aar Massif, Switzerland, and the Lepontine Dome, Italy, Tectonics, 28(5), TC5004, doi:10.1029/2008TC002387, 2009.

Vollmayr, T.: Strukturelle Ergebnisse der Kohlenwasserstoffexploration im Gebiet von Thun, Schweiz, Eclogae Geol. Helv., 5 85(3), 531-539, 1992.

Wehrens, P., Baumberger, R., Berger, A. and Herwegh, M.: How is strain localized in a meta-granitoid, mid-crustal basement section? Spatial distribution of deformation in the central Aar massif (Switzerland), J. Struct. Geol., 94, 47-67, doi:10.1016/j.jsg.2016.11.004, 2017.

Weidmann, M., Homewood, P., Morel, R., Berchten, J.-D., Bucher, H., Burri, M., Cornioley, J.-D., Escher, P., Rück, P.,

10 Tabotta, A. and Zahner, P.: Geological Atlas of Switzerland 1:25000, Map sheet Châtel-St-Denis (LK 1244), Federal Office of Topography swisstopo, Wabern, Switzerland., 1993.

Weisenberger, T. B., Rahn, M. K., van der Lelij, R., Spikings, R. A. and Bucher, K.: Timing of low-temperature mineral formation during exhumation and cooling in the Central Alps, Switzerland, Earth Planet. Sci. Lett., 327-328, 1-8, doi:10.1016/j.epsl.2012.01.007, 2012.

15 Whipple, K. X.: The influence of climate on the tectonic evolution of mountain belts, Nat. Geosci., 2(2), 97-104, doi:10.1038/ngeo413, 2009.

Willett, S. D. and Schlunegger, F.: The last phase of deposition in the Swiss Molasse Basin: from foredeep to negative-alpha basin, Basin Res., 22(5), 623-639, doi:10.1111/j.1365-2117.2009.00435.x, 2010.

Willett, S. D., Schlunegger, F. and Picotti, V.: Messinian climate change and erosional destruction of the central European 20 Alps, Geology, 34(8), 613, doi:10.1130/G22280.1, 2006.

Wolf, R. A., Farley, K. A. and Silver, L. T.: Helium diffusion and low-temperature thermochronometry of apatite, Geochim. Cosmochim. Acta, 60(21), 4231-4240, doi:10.1016/S0016-7037(96)00192-5, 1996.

Zaugg, A., Löpfe, R., Kriemler, M. and Kempf, T.: Geological Atlas of Switzerland 1:25000, Federal Office of Topography swisstopo, Wabern, Switzerland., 2011. 
Solid Earth Discuss., https://doi.org/10.5194/se-2019-56

Manuscript under review for journal Solid Earth

Discussion started: 20 March 2019

(c) Author(s) 2019. CC BY 4.0 License.

Table 1. Apatite (U-Th-Sm)/He dating results.

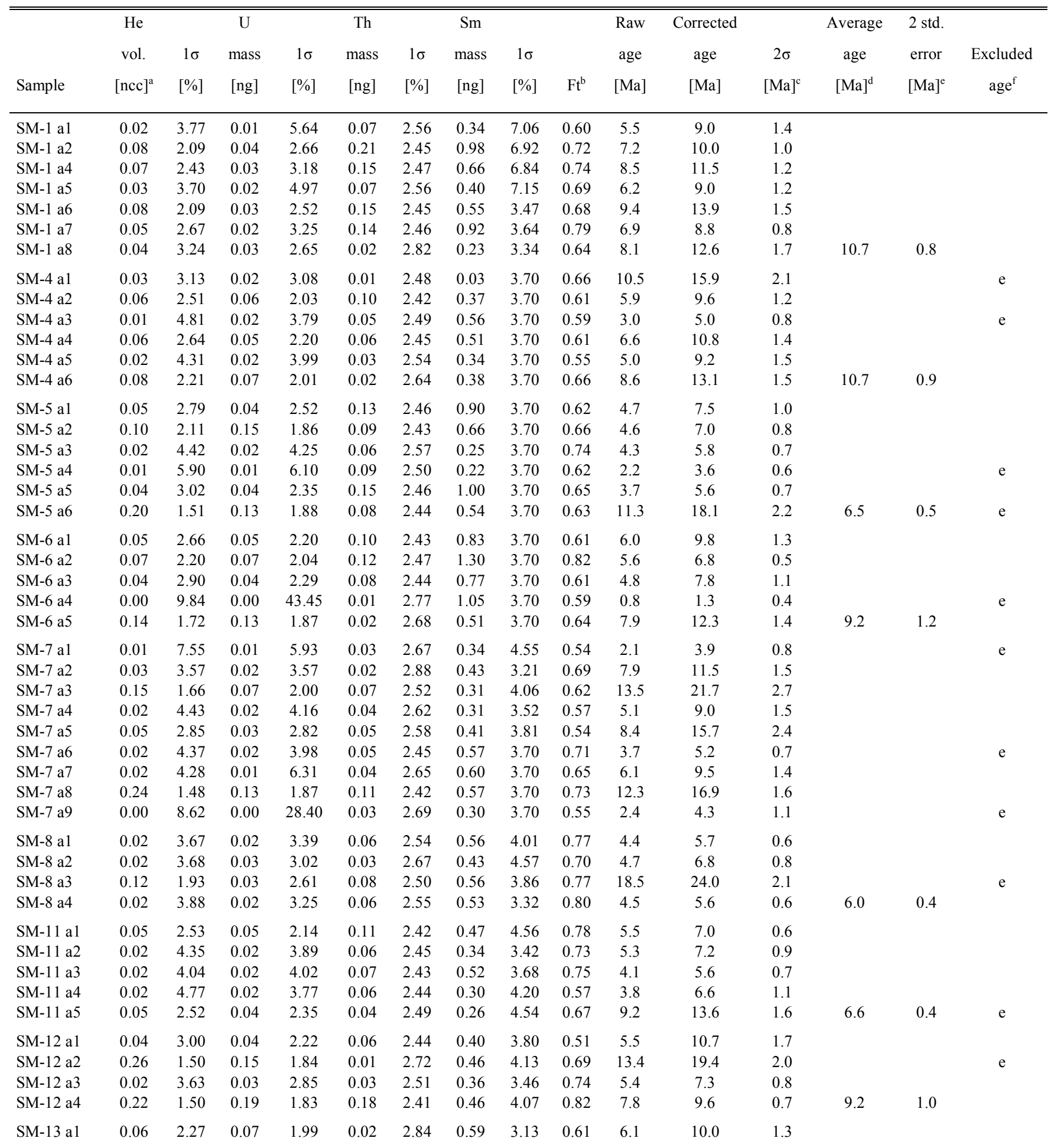


Solid Earth Discuss., https://doi.org/10.5194/se-2019-56

Manuscript under review for journal Solid Earth

Discussion started: 20 March 2019

(c) Author(s) 2019. CC BY 4.0 License.

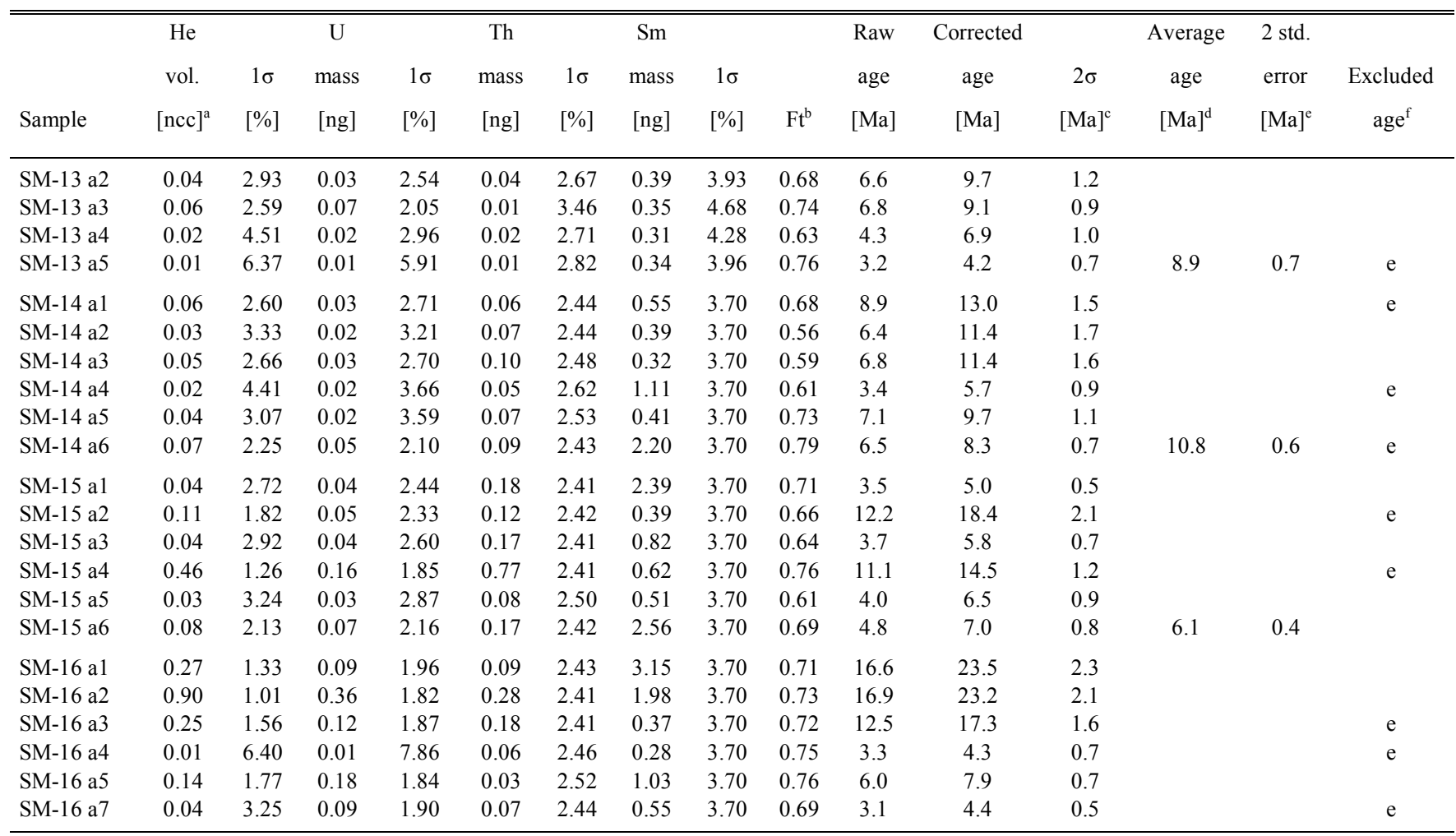

${ }^{\mathrm{a}} \mathrm{Amount}$ of helium is given in nano-cubic-cm in standard temperature and pressure.

${ }^{b}$ Ejection correction $(\mathrm{Ft})$ : correction factor for alpha-ejection (Farley et al., 1996; Hourigan et al., 2005).

${ }^{c}$ Uncertaintiy of the single grain age is given as 2 sigma in \% (or in Ma) and it includs both the analytical uncertainty and the estimated uncertainty of the Ft.

${ }^{\mathrm{d} A v e r a g e}$ ages for totally reset samples were calculated as the unweighted arithmetic mean.

${ }^{\mathrm{g}}$ Uncertainty of the sample average age is 2 standard error, as $(\mathrm{SD}) /(\mathrm{n}) 1 / 2$; where $\mathrm{SD}=$ standard deviation of the age replicates and $\mathrm{n}=$ number of age determinations.

${ }^{\mathrm{f}}$ Ages with a substantial first He re-extract ( $>4 \%$ ) and/or a total analytical error of $>10 \%$ have been excluded. Outliers on the [He]-P plot have also been excluded (Vermeesch, 2008). 
Solid Earth Discuss., https://doi.org/10.5194/se-2019-56

Manuscript under review for journal Solid Earth

Discussion started: 20 March 2019

(c) Author(s) 2019. CC BY 4.0 License.
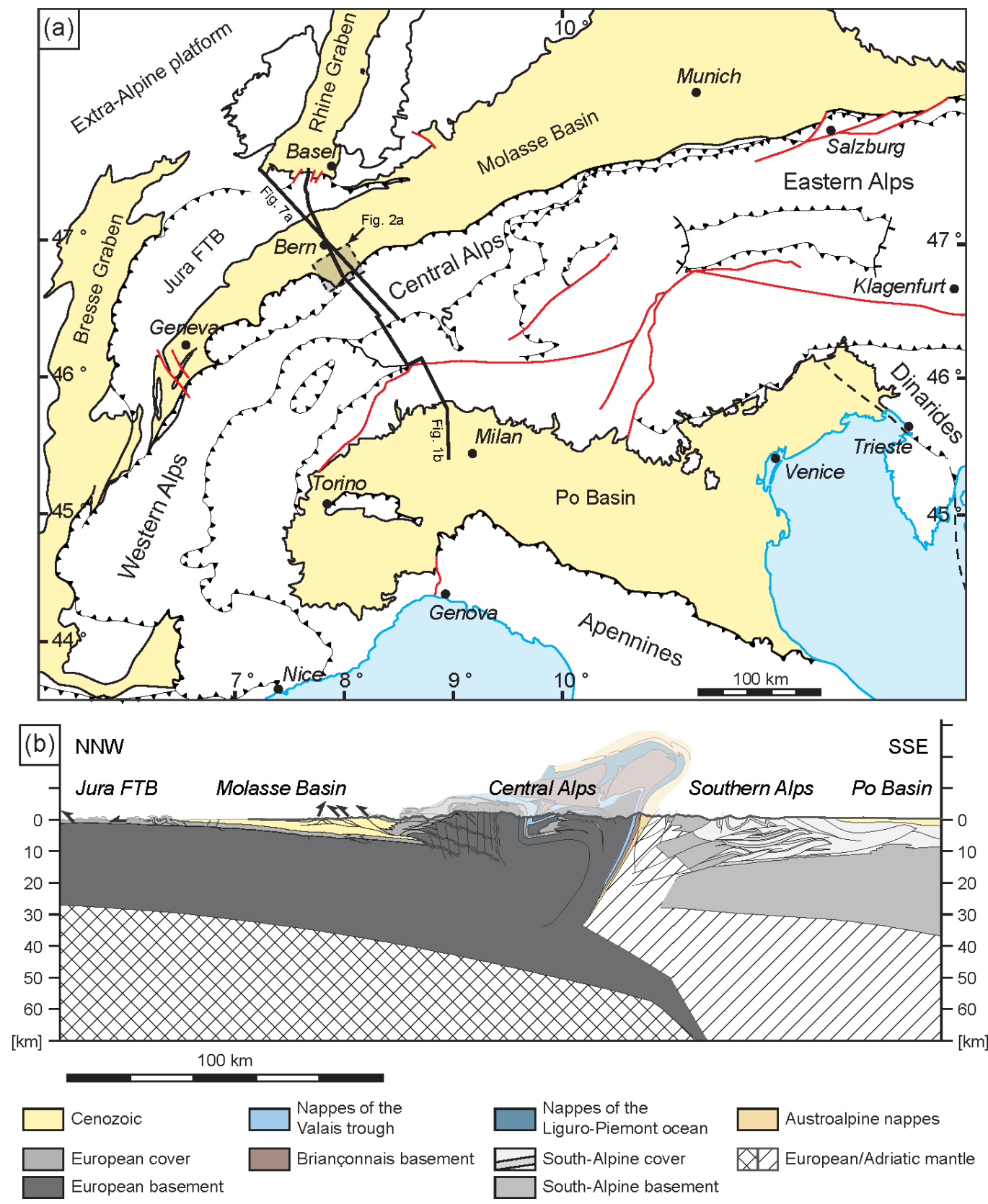

Figure 1. (a) Tectonic map of the European Alps and its foreland basins (adapted from Pfiffner, 2016). Traces of the crosssection in Fig. 1b and Fig. 7a are given as bold black lines. The study area (Fig. 2a) is denoted by a dashed rectangle. (b)

5 Cross-section through the Central Alps (compiled from Buxtorf, 1916; Herwegh et al., 2017; Mock and Herwegh, 2017; Pfiffner, 2009; Rosenberg and Kissling, 2013). FTB, fold-and-thrust belt. 
Solid Earth Discuss., https://doi.org/10.5194/se-2019-56

Manuscript under review for journal Solid Earth

Discussion started: 20 March 2019

(c) Author(s) 2019. CC BY 4.0 License.

(c) (1)
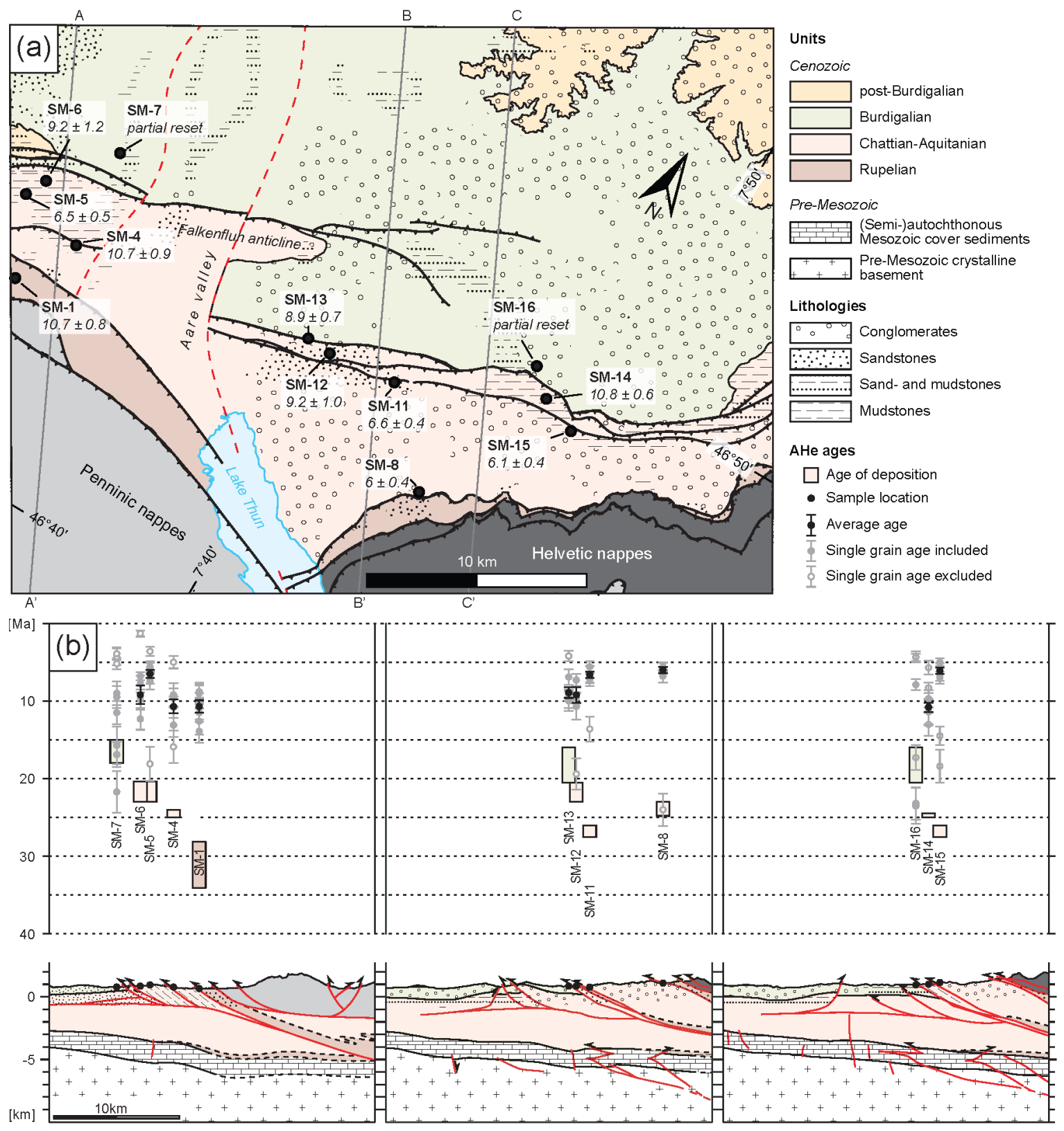

Figure 2. (a) Litho-tectonic map of the Lake Thun area showing sample locations and corresponding average apatite (U-Th$\mathrm{Sm}) / \mathrm{He}(\mathrm{AHe})$ ages. Traces of cross-sections A-A', B-B', and C-C' in Fig. $2 \mathrm{~b}$ are given as black lines. The location of the

5 sampling area is shown as a dashed rectangle in Fig. 1a. (b) Cross-sections through the sampling area west (A-A') and east of the Aare valley (B-B' and C-C'), showing single grain and average AHe ages. 
Solid Earth Discuss., https://doi.org/10.5194/se-2019-56

Manuscript under review for journal Solid Earth

Discussion started: 20 March 2019

(c) Author(s) 2019. CC BY 4.0 License.

\section{(c) (1)}
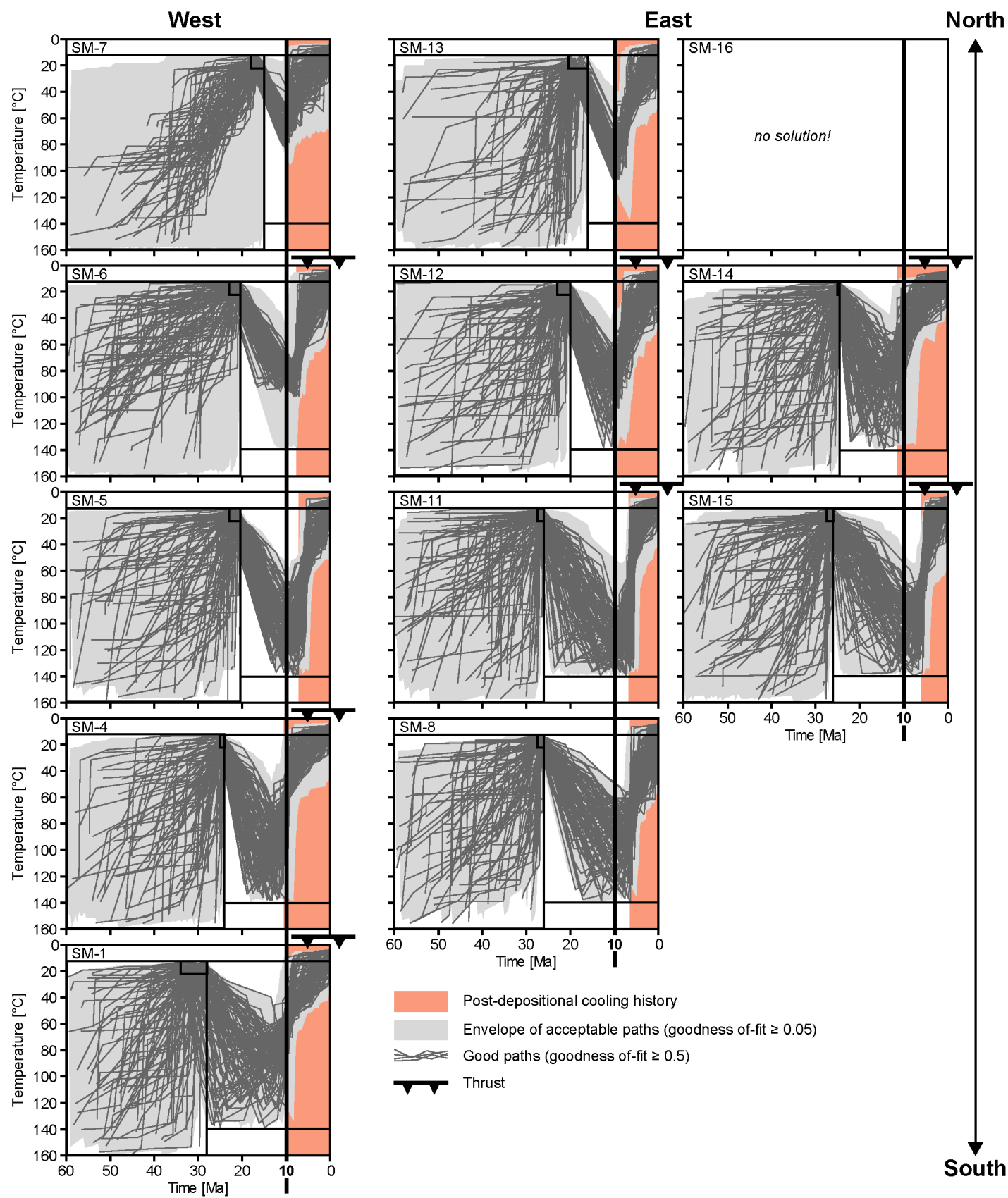

Figure 3. Thermal evolution of samples. The results from inverse modeling of apatite (U-Th-Sm)/He (AHe) ages with the HeFTy software (Ketcham, 2005) show the time-temperature history of the samples discussed in the text. Modeling constraints are shown as black boxes. The bold black lines at $10 \mathrm{Ma}$ serve as a visual time reference. The thermal histories

5 for the different samples are aligned from north to south and from east to west according to their sample location. 
Solid Earth Discuss., https://doi.org/10.5194/se-2019-56

Manuscript under review for journal Solid Earth

Discussion started: 20 March 2019

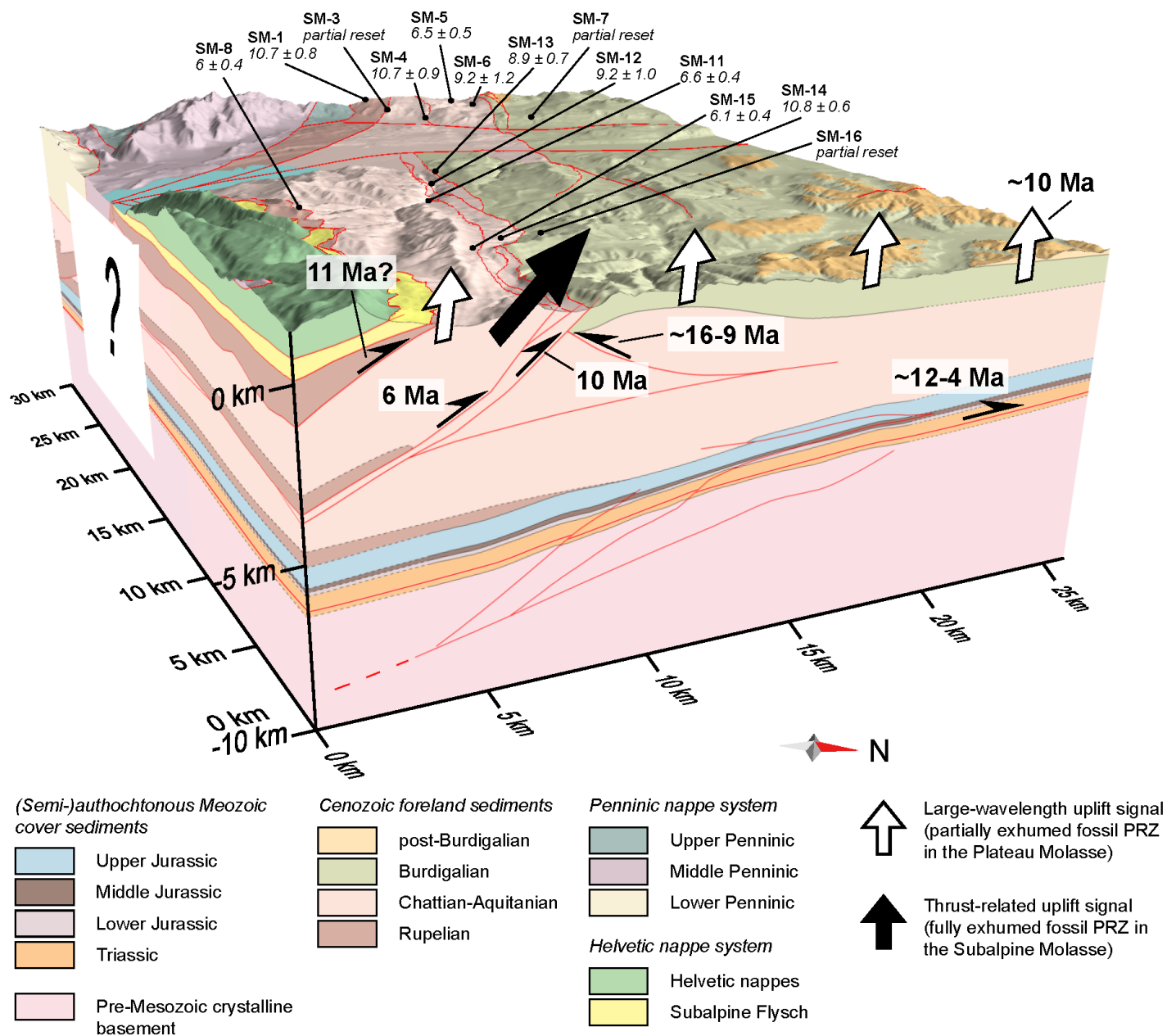

Figure 4. Block model of with sample locations and corresponding average (U-Th-Sm)/He ages. The construction of the block model is based on surface (Beck, 1945; Haus, 1937; Jordi, 2012; Rutsch, 1947; Schlunegger et al., 1993, 1997) and subsurface (2D seismic interpretation; Mock and Herwegh, 2017) geological information. PRZ, partial retention zone. 
Solid Earth Discuss., https://doi.org/10.5194/se-2019-56

Manuscript under review for journal Solid Earth

Solid Earth

Discussion started: 20 March 2019

Discussions

(c) Author(s) 2019. CC BY 4.0 License.

(c) (1)
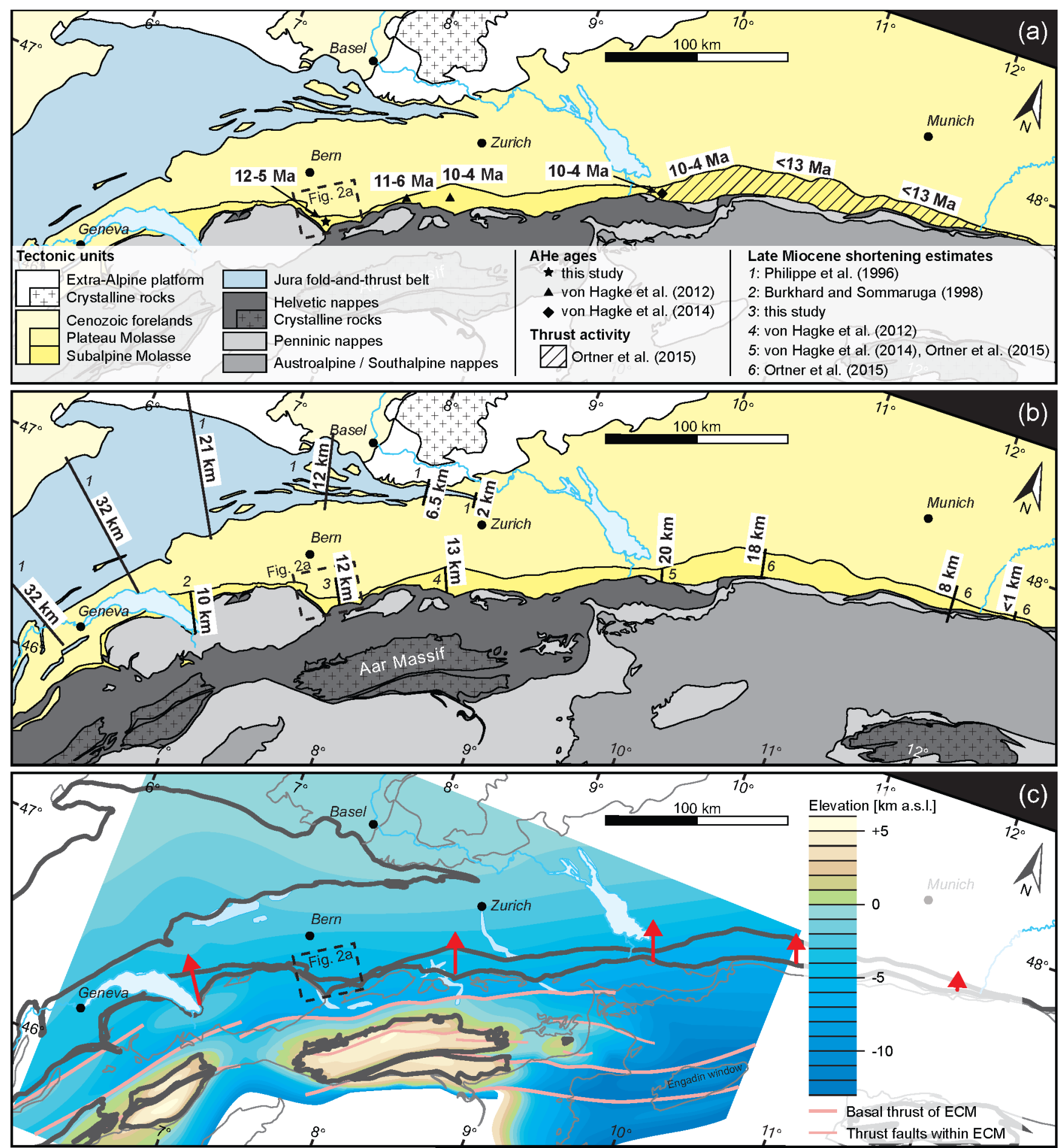
Solid Earth Discuss., https://doi.org/10.5194/se-2019-56

Manuscript under review for journal Solid Earth

Discussion started: 20 March 2019

(c) Author(s) 2019. CC BY 4.0 License.

Figure 5. Along-strike variations in late Miocene deformation of the North Alpine foreland of the Central Alps. (a) Tectonic map of the northern Central and Eastern Alps (modified from Schmid et al., 2004) and activity of thrusting in the Subalpine Molasse deduced from AHe ages and field observations. (b) Tectonic map of the northern Central and Eastern Alps (modified from Schmid et al., 2004) and estimated amount of late Miocene shortening in the North Alpine foreland (i.e.,

5 Subalpine Molasse, and Jura FTB). Estimates from the Subalpine Molasse record minimum shortening. (c) Top basement map of the Central Alps (modified from Pfiffner, 2011) showing the highly non-cylindrical hinterland architecture with the high relief domains of the External Crystalline Massifs (ECMs). Red arrows indicate the constant late Miocene deformation signal with a slight decrease in horizontal shortening recorded in the North Alpine foreland. 
Solid Earth Discuss., https://doi.org/10.5194/se-2019-56

Manuscript under review for journal Solid Earth

Discussion started: 20 March 2019

(c) Author(s) 2019. CC BY 4.0 License.

\section{(c) (1)}

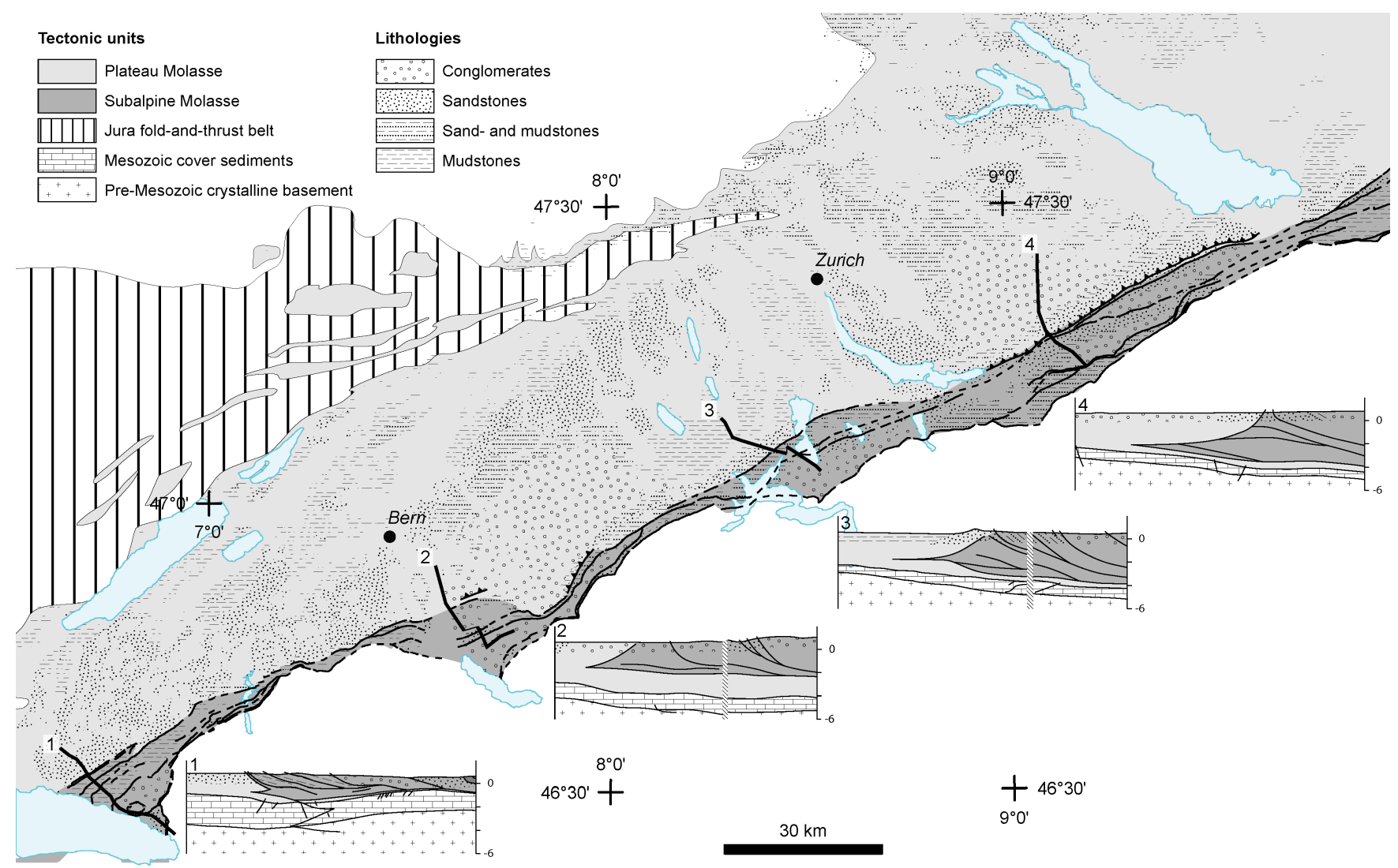

Figure 6. Litho-tectonic map of the Swiss Molasse Basin (modified from Landesgeologie, 2005). Cross-sections 1-4 are based on 2D seismic interpretation (cross-section 2, Mock and Herwegh, 2017; cross-sections 1, 3, and 4, Sommaruga et al., 2012). 
Solid Earth Discuss., https://doi.org/10.5194/se-2019-56

Manuscript under review for journal Solid Earth

Discussion started: 20 March 2019

(c) Author(s) 2019. CC BY 4.0 License.

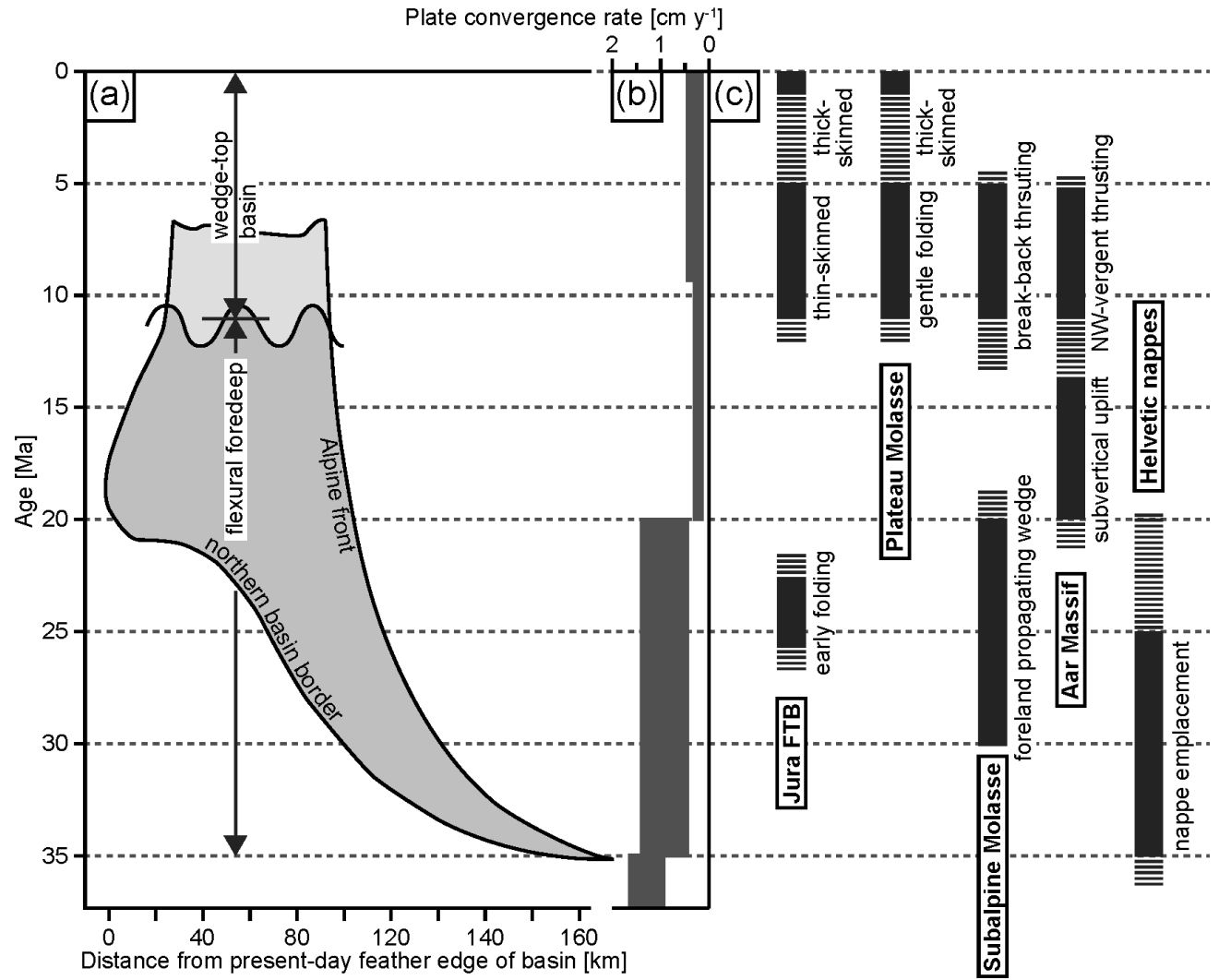

Figure 7. Oligocene to present-day evolution of the northern Central Alps. (a) Temporal evolution of the Molasse Basin architecture (adapted from Schlunegger and Kissling, 2015). The location of the section is given in Fig. 1a. (b) Rates of plate convergence between Adria and Europe (Handy et al., 2010; Schmid et al., 1996). (c) Tectonic evolution of the major 5 tectonic units of the northern Central Alps. FTB, fold-and-thrust belt. 